Technical Report 1348

\title{
Preparing Brigade Combat Team Soldiers for Mission Readiness Through Research on Intangible Psychological Constructs and their Applications: Validation and Pilot
}

Steven N. Aude

Kenneth Nicely

Michael A. Lodato

ICF International

Christopher L. Vowels

U.S. Army Research Institute

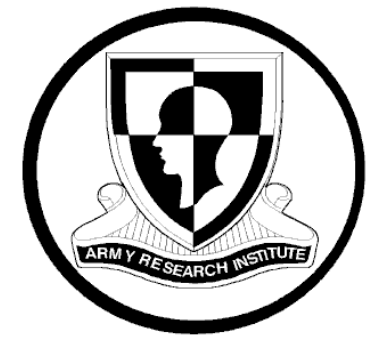

January 2015

United States Army Research Institute for the Behavioral and Social Sciences

Approved for public release; distribution is unlimited. 


\section{U.S. Army Research Institute for the Behavioral and Social Sciences}

\section{Department of the Army \\ Deputy Chief of Staff, G1}

\section{Authorized and approved:}

MICHELLE SAMS, Ph.D. Director

Research accomplished under contract

for the Department of the Army by

ICF International

Technical review by

Gia A. DiRosa, U.S. Army Research Institute

Mark C. Young, U.S. Army Research Institute

\section{NOTICES}

DISTRIBUTION: This Technical Report has been submitted to the Defense Information Technical Center (DTIC). Address correspondence concerning ARI reports to: U.S. Army Research Institute for the Behavioral and Social Sciences, Attn: DAPE-ARI-ZXM, $60006^{\text {th }}$ Street Building 1464 / Mail Stop: 5610), Fort Belvoir, VA 22060-5610.

FINAL DISPOSITION: Destroy his Technical Report when it is no longer needed. Do not return it to the U.S. Army Research Institute for the Behavioral and Social Sciences.

NOTE: The findings in this Technical Report are not to be construed as an official Department of the Army position, unless so designated by other authorized documents. 


\begin{tabular}{|c|c|c|c|c|c|}
\hline \multicolumn{6}{|c|}{ REPORT DOCUMENTATION PAGE } \\
\hline \multicolumn{2}{|c|}{$\begin{array}{l}\text { 1. REPORT DATE (dd-mm-yy) } \\
\text { January } 2015\end{array}$} & \multicolumn{2}{|c|}{$\begin{array}{l}\text { 2. REPORT TYPE } \\
\text { Final }\end{array}$} & \multicolumn{2}{|c|}{$\begin{array}{l}\text { 3. DATES COVERED (from. ... to) } \\
\text { November } 2011 \text { - September } 2012\end{array}$} \\
\hline \multirow{2}{*}{\multicolumn{4}{|c|}{$\begin{array}{l}\text { 4. TITLE AND SUBTITLE } \\
\text { Preparing Brigade Combat Team Soldiers for Mission Readiness } \\
\text { Through Research on Intangible Psychological Constructs and their } \\
\text { Applications: Validation and Pilot }\end{array}$}} & \multicolumn{2}{|c|}{$\begin{array}{l}\text { 5a. CONTRACT OR GRANT NUMBER } \\
\text { W5J9CQ-11-0009 }\end{array}$} \\
\hline & & & & \multicolumn{2}{|c|}{$\begin{array}{l}\text { 5b. PROGRAM ELEMENT NUMBER } \\
622785\end{array}$} \\
\hline \multirow{3}{*}{\multicolumn{4}{|c|}{$\begin{array}{l}\text { 6. AUTHOR(S) } \\
\text { Steven N. Aude, Kenneth Nicely, Michael A. Lodato; } \\
\text { Christopher L. Vowels }\end{array}$}} & \multicolumn{2}{|c|}{$\begin{array}{l}\text { 5c. PROJECT NUMBER } \\
\text { A790 }\end{array}$} \\
\hline & & & & \multicolumn{2}{|l|}{$\begin{array}{l}\text { 5d. TASK NUMBER } \\
370\end{array}$} \\
\hline & & & & \multicolumn{2}{|c|}{ 5e. WORK UNIT NUMBER } \\
\hline \multicolumn{4}{|c|}{$\begin{array}{l}\text { 7. PERFORMING ORGANIZATION NAME(S) AND ADDRESS(ES) } \\
\begin{array}{ll}\text { ICF Incorporated } & \text { U.S. Army Research Institute } \\
\text { 9300 Lee Highway } & \text { for the Behavioral and Social Sciences } \\
\text { Fairfax, VA 22031 } & 6000 \text { 6th Street } \\
& \text { Bldg 1464/Mail Stop 5610 } \\
& \text { Fort Belvoir, VA 22060 } \\
\end{array}\end{array}$} & \multicolumn{2}{|c|}{ 8. PERFORMING ORGANIZATION REPORT NUMBER } \\
\hline \multirow{2}{*}{\multicolumn{4}{|c|}{$\begin{array}{l}\text { 9. SPONSORING/MONITORING AGENCY NAME(S) AND ADDRESS(ES) } \\
\text { U.S. Army Research Institute } \\
\text { for the Behavioral and Social Sciences } \\
6000 \text { th Street } \\
\text { Bldg 1464/Mail Stop } 5610 \\
\text { Fort Belvoir, VA } 22060\end{array}$}} & \multicolumn{2}{|c|}{$\begin{array}{l}\text { 10. MONITOR ACRONYM } \\
\text { ARI }\end{array}$} \\
\hline & & & & \multicolumn{2}{|c|}{$\begin{array}{l}\text { 11. MONITOR REPORT NUMBER } \\
\text { Technical Report } 1348\end{array}$} \\
\hline \multicolumn{6}{|c|}{$\begin{array}{l}\text { 12. DISTRIBUTION/AVAILABILITY STATEMENT; Distribution Statement A. } \\
\text { Approved for public release; distribution is unlimited. }\end{array}$} \\
\hline \multicolumn{6}{|c|}{$\begin{array}{l}\text { 13. SUPPLEMENTARY NOTES } \\
\text { COR and Subject Matter POC: Christopher L. Vowels }\end{array}$} \\
\hline \multicolumn{6}{|c|}{$\begin{array}{l}\text { 14. ABSTRACT (Maximum } 200 \text { words): } \\
\text { The U.S. Army Research Institute is developing and piloting measures of Soldier initiative and perseverance to enhance } \\
\text { Soldier mental toughness and readiness for their assigned mission set. Potential uses of the measures are to both } \\
\text { assess and develop Soldier initiative and perseverance as part of their individual and collective unit training. In the } \\
\text { current research, evidence for construct validity was gathered by administering measures of initiative and perseverance } \\
\text { to } 151 \text { Soldiers. Additional evidence for construct validity and the usability of the measures in the field was obtained by } \\
\text { conducting a pilot test with } 10 \text { noncommissioned officers serving in positions of acting squad leader during Medical } \\
\text { Simulation Training Center training lanes. }\end{array}$} \\
\hline \multicolumn{6}{|c|}{$\begin{array}{l}\text { 15. SUBJECT TERMS } \\
\text { Initiative, perseverance, Soldier readiness, mental toughness, resiliency, hardiness }\end{array}$} \\
\hline \multicolumn{3}{|c|}{ SECURITY CLASSIFICATION OF } & $\begin{array}{l}\text { 19. LIMITATION OF } \\
\text { ABSTRACT }\end{array}$ & $\begin{array}{l}\text { 20. NUMBER OF } \\
\text { PAGES }\end{array}$ & $\begin{array}{l}\text { 21. RESPONSIBLE PERSON } \\
\text { (Name and Telephone Number) }\end{array}$ \\
\hline $\begin{array}{l}\text { 16. REPORT } \\
\text { Unclassified }\end{array}$ & $\begin{array}{l}\text { 17. ABSTRACT } \\
\text { Unclassified }\end{array}$ & $\begin{array}{l}\text { 18. THIS PAGE } \\
\text { Unclassified }\end{array}$ & $\begin{array}{l}\text { Unlimited } \\
\text { Unclassified }\end{array}$ & 46 & $\begin{array}{l}\text { Dorothy Young } \\
703-545-2316\end{array}$ \\
\hline
\end{tabular}




\title{
Preparing Brigade Combat Team Soldiers for Mission Readiness Through Research on Intangible Psychological Constructs and Their Applications: Validation and Pilot
}

\author{
Steven N. Aude \\ Kenneth Nicely \\ Michael A. Lodato \\ ICF International \\ Christopher L. Vowels \\ U.S. Army Research Institute
}

Fort Hood Research Unit

Brian T. Crabb, Chief

United States Army Research Institute

for the Behavioral and Social Sciences

January 2015

Approved for public release; distribution is unlimited. 
We offer our sincere thanks to the Soldiers assigned to III Corps and Fort Hood, TX, who participated in the research on the present topic. Additionally, we would like to thank the cadre of the Fort Hood Medical Simulation Training Center for their support of the pilot phase of this research. 
PREPARING BRIGADE COMBAT TEAM SOLDIERS FOR MISSION READINESS THROUGH RESEARCH ON INTANGIBLE PSYCHOLOGICAL CONSTRUCTS AND THEIR APPLICATIONS: VALIDATION AND PILOT

\section{EXECUTIVE SUMMARY}

Research Requirement:

This report is the third phase of research to identify and develop measures for intangibles that contribute to Soldier mission readiness. The U.S. Army Research Institute for the Behavioral and Social Sciences (ARI) has used the adjective intangible in the context of this research to describe psychological constructs that contribute to the mental readiness of Soldiers to perform their assigned mission set. The first phase of research consisted of a broad review of the literature designed to identify the domain of intangible constructs. Data collection with Soldiers bounded this domain and further identified the most important intangible constructs to Soldier mission readiness to be: initiative, will, grit and hardiness; further analyses focused the research on initiative and perseverance. Additionally, effective learning methods for the training of such intangibles were identified. The objective in the second phase of research was to identify training events that would lend themselves to the training and measurement of intangibles critical to Soldier mission readiness. The purpose of the third phase, and focus of the present report, was to validate measures of select intangibles and pilot them in a realistic training environment.

Procedure:

This phase of the research involved two tasks. In Task 1, the measures of initiative and perseverance were administered to 151 active duty Soldiers. The purpose of this task was to confirm the construct validity of the measures. In Task 2, the measures were administered to 10 squad leaders taking part in training at the Medical Simulation Training Center (MSTC). The purpose of this task was to assess general characteristics of measure face validity as well as confirm that the measures can be effectively and efficiently administered in a field environment.

Findings:

This study provided strong support for the construct validity of the initiative and perseverance measures. In conducting Task 1, strong statistical support was found for retaining the 18-item measures for both initiative and persistence. Results of item functionality analyses supported the use of bipolar response scales in measuring these intangible constructs. Results of principal component analyses indicated that for each measure, all 18 items loaded onto one component. Both measures also demonstrated strong internal consistency. Results of the pilot study in Task 2 provided evidence that assessing these intangibles during training is viewed as important and credible by Soldiers and leaders that would employ them. The length of both measures was found to be reasonable and item wording and instructions were reported by Soldiers to be clear and understandable. 
Utilization and Dissemination of Findings:

The findings from the third phase of this research provide evidence that the developed measures of Soldier initiative and perseverance are practical and usable in a field training environment, (e.g., situational training exercises, field training exercises, gunnery, combat training centers, etc.). These measures can be used by superiors or otherwise experienced leaders to rate a given Soldier's level of initiative and perseverance. Use of the measures could be further enhanced by the addition of developmental materials. Such materials would be especially useful for those who receive low ratings. 


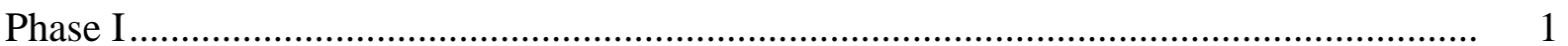

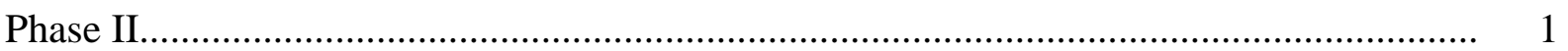

Phase III: Current Research ...................................................................................... 2

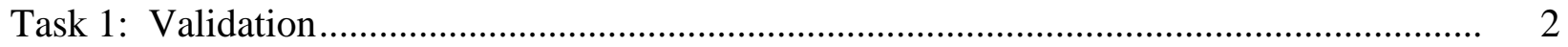

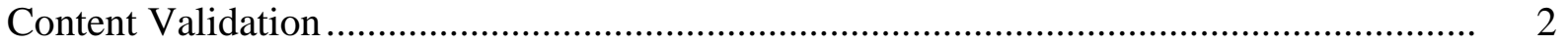

Construct Validation .............................................................................................. 4

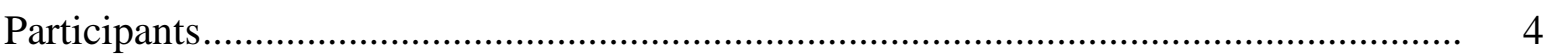

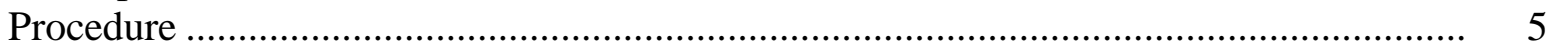

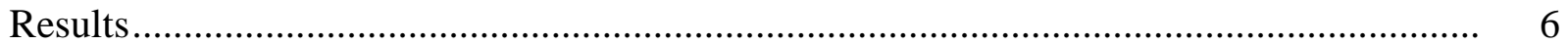

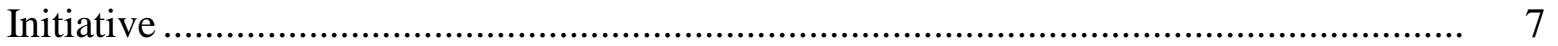

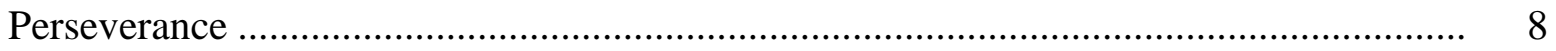

Summary of Analysis for Initiative and Perseverance Measures ................................... 10

Task 2: Pilot of Assessments ................................................................................. 11

Participants....................................................................................................... 11

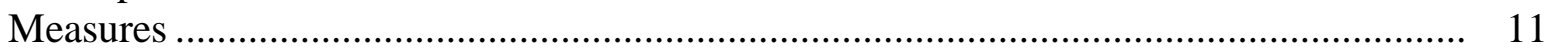

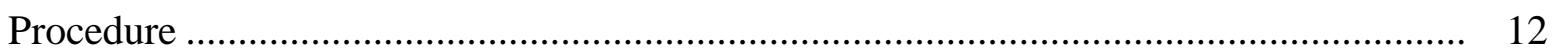

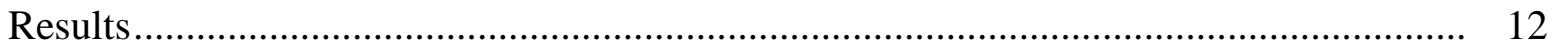

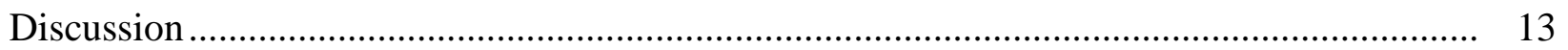

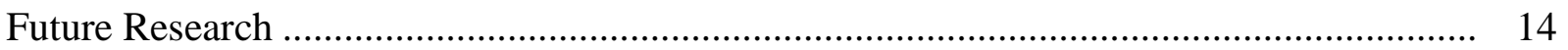

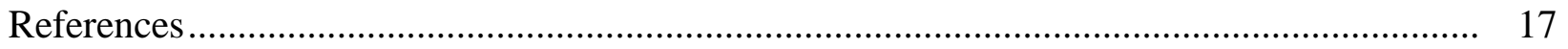

\section{APPENDICES}

Appendix A: Initiative Measure - Task 1............................................................................. A-1

Appendix B: Perseverance Measure - Task 1 …………………………………………....... B-1

Appendix C: Initiative Measure - Task 2 ............................................................................. C-1

Appendix D: Perseverance Measure - Task 2 …………………………………………..... D-1 


\section{Preparing Brigade Combat Team Soldiers for Mission Readiness Through Research on Intangible Psychological Constructs and Their Applications: Validation and Pilot}

The goal of the Brigade Combat Team (BCT) Preparatory Skill Set project is to develop content- and construct-valid measures of intangible psychological constructs and identify effective methods and situations in which intangibles can be trained at the tactical unit level. In this research, the U.S. Army Research Institute for the Behavioral and Social Sciences (ARI) uses the term intangible to describe psychological constructs that contribute to Soldier mission readiness. Soldier mission readiness describes Soldiers' preparedness for a wide range of missions (e.g., disaster relief, short-term contingency operations, long term deployments, counterinsurgency operations, full range of military operations). There have been three phases to this research; the current study is the third. Below, we provide brief summaries of the first two phases and introduce Phase III.

\section{Phase I}

The purpose of Phase I of this research was the identification of psychological constructs critical for Soldier mission readiness (Aude, Bryson, Keller-Glaze, Nicely, \& Vowels, 2014). To support the research objectives, a comprehensive literature review including academic and military sources was conducted and a combined total of approximately 100 Soldiers and leaders were either interviewed or participated in focus groups. Several constructs were identified, each of which had multiple sub-constructs embedded within them. Data collection with Soldiers and leaders assisted in the development of a concise list of four key intangibles deemed most critical to mission readiness, namely: hardiness, grit, will, and initiative.

\section{Phase II}

Phase II of the research consisted of a literature review and data collection focused on the measurement of hardiness, grit, will, and initiative, as well as the identification of what types of training/learning environments are most conducive to the exhibition or demonstration of these four intangible constructs (Aude, Keller-Glaze, Nicely, Shuffler, \& Vowels, 2014). During data collection, interviews were conducted with a combined total of approximately 50 Soldiers and leaders. Results indicated that a number of training environments were the most effective environments for the type of experiential and realistic conditions needed to train intangibles (e.g., Combat Training Centers). Interviewees suggested that any given Soldier's (immediate) superior would be the most accurate at assessing intangible psychological constructs displayed by them. To provide the basis for such assessments, performance indicators for each of the intangible constructs were identified. 


\section{Phase III: Current Research}

Phase III of this research involved two primary tasks, each consisting of several subtasks:

1. Develop and establish the validity of selected intangible constructs. Develop content valid measures. Conduct psychometric analyses of Soldier-administered measures to determine if construct validity and reliability statistics are acceptable and refine the measures accordingly.

2. Pilot test and evaluate the measures in a field training environment. Have Soldiers use the measures and report on their general acceptance (face validity). Evaluate the overall effectiveness and efficiency of the measures in a field training environment.

In sum, the present research builds on the previous phases of intangible construct content and measurement literature reviews, together with data collections, to establish the validity of Soldier measures of intangibles critical to mission readiness. Furthermore, the pilot test demonstrates Soldiers can effectively and efficiently utilize the instruments in a realistic training environment.

\section{Task 1: Validation}

\section{Content Validation}

Previous phases of this research informed the development of intangible measures and their content. Data collection participants, for example, had indicated that a Soldier's superior or an objective rater (e.g., Combat Training Center observer-trainer) would possess the requisite expertise to rate him/her in terms of intangible constructs. Consequently, intangible measures and their instructions were developed with these raters in mind. The measures were also designed for administration in a field environment. This design parameter necessitated measures that could be quickly and accurately scored. Third, ratings were expected to be largely observational or based on performance indicators that are available soon thereafter. So, too, the complete rating of a Soldier on an intangible ought to take place during or immediately following the exhibition of a given intangible. All of these design parameters facilitate the rating process and help ensure the rating of intangible construct content is accurate and its scores are interpretable and relevant.

Content for measuring intangible constructs was developed using the previous measurement literature review and items identified therein associated with initiative, grit, will, and hardiness constructs. Data from Soldier subject matter experts also contributed to item generation. For example, during Phase I interviews and focus groups, participants were asked to identify indicators of initiative, grit, will, and hardiness (Aude, Bryson, Keller-Glaze, Nicely, \& Vowels, 2014). Employing the previously mentioned content sources, three members of the research team independently developed draft item lists. Following item generation, the three lists of items were reviewed and consolidated (e.g., redundant items removed) resulting in one draft item pool for measuring intangible constructs.

To confirm the scales or sub-dimensions within this item pool, the research team then used a sorting procedure described in Spreitzer, McCall, and Mahoney (1997). First three 
members of the research team independently reviewed the draft list of items and placed content similar items into groups for the purpose of creating scales (e.g., a group of items representing a sub-dimension). Each researcher then examined each sub-dimension grouping and assigned a representative name for each scale. The item groupings and scale names of each researcher were then presented to the entire research team and compared. In general, there was consistency across researchers in items associated with the initiative construct. However, items associated with hardiness, grit, and will were largely intermingled. In the research team's estimation, the combination of hardiness, grit, and will seemed to be more a general measure of perseverance than any of the three constructs in particular. Consequently, it was agreed upon by the research team that this pool of intangible items was best titled as "perseverance."

Consistent with the need for quick but accurate field use, a bipolar rating scale was selected for use with the measures of initiative and perseverance. Bipolar scales possess some of the advantages of a behaviorally anchored rating scale yet are not as time intensive. At each end of the bipolar scale a behavioral description is provided to anchor all ratings on or between the two ends of the scale. A 7-point rating scale was used for each item as research has shown bipolar rating scales produce the most reliable results when using a 7-point rating scale (Krosnick \& Tahk, n.d.). Listed below are two examples of bipolar items, the first from the initiative measure, and the second from the perseverance measure.

Initiative example

\begin{tabular}{|l|l|l|l|l|l|l|l|l|}
\hline $\begin{array}{l}\text { Required detailed } \\
\text { orders and a lot of } \\
\text { inspiration from } \\
\text { leaders to } \\
\text { accomplish tasks }\end{array}$ & 1 & 2 & 3 & 4 & 5 & 6 & 7 & $\begin{array}{l}\text { Demonstrated the } \\
\text { ability to self-start, push } \\
\text { self, and be proactive in } \\
\text { accomplishing tasks }\end{array}$ \\
\hline
\end{tabular}

Perseverance example

\begin{tabular}{|l|l|l|l|l|l|l|l|l|}
\hline $\begin{array}{l}\text { Quit when challenged } \\
\text { physically }\end{array}$ & 1 & 2 & 3 & 4 & 5 & 6 & 7 & $\begin{array}{l}\text { Kept going, even when } \\
\text { exhausted, hungry, afraid, } \\
\text { cold, and wet }\end{array}$ \\
\hline
\end{tabular}

Appendix A and B, respectively, provide the complete list of 18 items for both the initiative and perseverance measures. Measure instructions specified that selecting a 1 on the bipolar scale indicated that the rater believed the ratee's behavior completely resembled the behavior on the left. Selecting a 7 indicated that the rater believed the ratee's behavior completely resembled the behavior on the right. A "Not Observed" option was also included. The full scale descriptions are provided below.

1 - Completely resembled behavior on left

2 - Mostly resembled behavior on left

3 - Slightly resembled behavior on left

4 - In between behaviors on left and right 
5 - Slightly resembled behavior on right

6 - Mostly resembled behavior on right

7 - Completely resembled behavior on right

Not Observed

\section{Construct Validation}

Participants. Content valid measures of initiative and perseverance were administered to a total of 151 active duty Soldiers to glean data necessary for statistical construct validation. Soldiers who participated represented various branch/functional areas, such as, Infantry, Armor, Engineer, Quartermaster, and Signal. The average time in service among Soldiers was 10 years and 8 months with only five participants having had three years or less of time in service. On average, Soldiers had been on between 2 and 3 deployments since 2001, with eight Soldiers having not yet been deployed. Consequently, participants met the criteria of being experienced Soldiers capable of rating other Soldiers on measures of intangible constructs. Tables 1 and 2 display the rank and positions of the experienced Soldiers who participated.

Table 1.

Participant Rank

Frequency Percent

\begin{tabular}{lcc}
\hline SGT & 63 & 41.7 \\
SSG & 43 & 28.5 \\
SFC & 17 & 11.3 \\
CPT & 8 & 5.3 \\
1LT & 7 & 4.6 \\
CW2 & 4 & 2.6 \\
Missing & 3 & 2.0 \\
2LT & 2 & 1.3 \\
MSG & 2 & 1.3 \\
MAJ & 1 & .7 \\
1SG & 1 & .7 \\
Total & 151 & 100.0 \\
\hline
\end{tabular}


Table 2.

Participant Positions

\begin{tabular}{lcc}
\hline & Frequency & Percent \\
\hline Battalion Primary Staff & 4 & 2.6 \\
Brigade-level Primary Staff & 3 & 2.0 \\
Brigade-level XO & 1 & .7 \\
Company/Battery Commander & 1 & .7 \\
Company/Battery XO & 3 & 2.0 \\
First Sergeant & 5 & 3.3 \\
Other company grade officer & & \\
position & 4 & 2.6 \\
Other NCO position & 19 & 12.6 \\
Platoon Leader & 2 & 1.3 \\
Platoon Sergeant & 24 & 15.9 \\
Squad/Section/Team Leader & 79 & 52.3 \\
Warrant officer position & 4 & 2.6 \\
Missing & 2 & 1.3 \\
Total & & 100.0 \\
\hline
\end{tabular}

Procedure. The questionnaires took approximately 30 to 45 minutes to complete, and began with a privacy act statement and informed consent. Soldiers were asked to sign these forms and given the option to not participate in the study. Next, they were asked to complete a demographic questionnaire that requested basic information including rank, time in service, position, recent deployment, branch/functional area, and current military status (i.e., active, Reserve, National Guard).

Following the demographic questionnaire, Soldiers were given verbal instructions for completing the perseverance and initiative questionnaires. Specifically, they were informed that they would be completing two questionnaires and that each questionnaire would take approximately 5-10 minutes to complete. Participants were then told that they would be asked to provide ratings on a fellow Soldier whom they recently observed going through a difficult work related task, mission, or assignment. Further, they were told that they could refer to the same Soldier for both questionnaires or refer to one Soldier for the first questionnaire and another Soldier for the second questionnaire. They were also told that the Soldier(s) they were rating could be one that performed either effectively or ineffectively on the task, mission, or 
assignment. The participants were assured that their ratings of their fellow Soldier would remain confidential and anonymous and that their data would not be used for evaluative purposes or personnel decisions.

Participants were then asked to read the instructions on the questionnaire. Questionnaire instructions described what was needed to effectively complete the questionnaire and demonstrated how to correctly apply the bipolar scales. It was explained that using the bipolar scales, Soldiers would be providing ratings on various behaviors related to important intangible attributes (see Appendix C \& D). To avoid biases and rating errors, they were explicitly told to provide ratings on the target Soldier's actual performance on a specific, difficult work-related task, mission, or assignment, rather than their general impression of the target Soldier (note: target Soldier refers to the person that the rater has chosen to evaluate and provide ratings on). For the initiative measure, participants were prompted to think specifically about a difficult work-related task, mission, or assignment that required the target Soldier to act using discretion. For the perseverance measure, participants were prompted to think about a difficult work-related task, mission, or assignment that required effort to do or achieve something despite difficulties, failure or opposition.

To ensure that participants were thinking about and providing ratings on another Soldier's performance during one training event, the instructions asked them to provide a brief written description of the difficult work related, task mission, or assignment on which their rating would be based. Participants were also asked to indicate their role in that situation.

In addition to the items in each measure, raters were asked to complete four measure evaluation items at the conclusion of each questionnaire. These items were designed to gather some information that would be useful toward criterion validity (1 and 2) and item reliability (3 and 4). The four items displayed below followed administration of the initiative measure.

1. Rate the Soldier's overall effectiveness at the difficult work related task, mission or assignment. (7-point scale: Very ineffective - Very effective)

2. In performing this difficult work related task, mission or assignment, the Soldier displayed initiative. (7-point scale: Strongly disagree - Strongly agree)

3. The items in this questionnaire were easy to understand. (7-point scale: Strongly disagree - Strongly agree)

4. If any of the items were unclear, please list the item numbers. (write-in response)

\section{Results}

For each measure, the research team initially examined item functionality and descriptive statistics. We then conducted a principal component analysis (PCA) with varimax rotation to determine if all of the items loaded onto the same component, and whether there was evidence to discard any items. In addition, we conducted reliability analyses including calculation of scale reliabilities if items were deleted to assess internal consistency and further investigate if the 
measures could be improved by refining or deleting items. The results of these analyses for each of the two measures are described below.

Initiative. The following descriptive statistics describe the item functionality. The range for all of the items in the initiative measure was six, indicating that Soldiers used all of the response options on the bipolar response scale. The means for these items ranged from 3.82 to 4.46, close to the center point of the scale, suggesting that Soldiers' responses did not skew negative or positive. Lastly, the standard deviations for the items on the initiative measure ranged from 2.0 to 2.25 , which indicates that there was adequate variance in the respondent ratings across all of the items.

The PCA conducted with the initiative data revealed only one component with an eigen value greater than 1 (13.991). Inspection of the scree plot also revealed a steep break after the first component (see Figure 1). Finally, all 18 items loaded onto the first component with component loadings greater than 0.7. This provided strong evidence for retaining all 18 items in a measure of termed initiative. The component and its items appear to be measuring a general action orientation taken at one's own instigation. The individual is proactive and anticipatory of what comes next and how it needs to be addressed. There is a sense of ownership and responsibility for what needs to be done (see Appendix C).

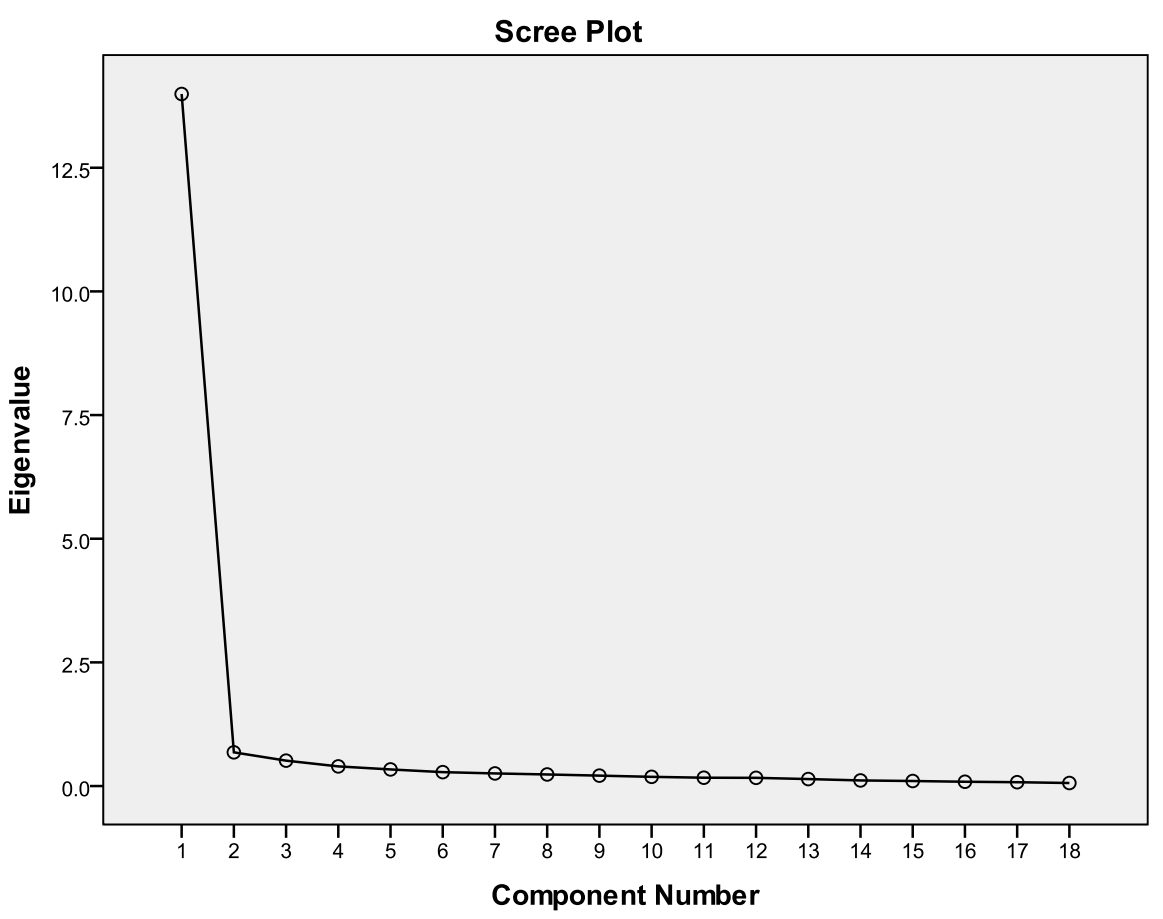

Figure 1. Scree plot depicting the eigen values for each component resulting from a principal component analysis of the 18 initiative items.

Overall, the measure demonstrated strong internal consistency $(\alpha=0.98)$. Further, results indicated that reliability would not be increased by discarding any of the items. Results of both the PCA and reliability analyses supported retaining all 18 items and provided evidence that all 18 items assessed the same construct, namely initiative. 
Participants were also asked to respond with their level of agreement to the item: "The items in this questionnaire were easy to understand.” Results indicated that $80 \%$ of Soldiers demonstrated some level of agreement, with only $11 \%$ indicating some level of disagreement. These results suggest that the vast majority of Soldiers found the items in the questionnaire easy to understand which underlies the statistical analysis of reliability. When Soldiers were asked to identify items that they thought were unclear, only one participant identified an item. The participant identified item 16 (see Appendix A), and suggested that, "SM [Service members] do not often see the full commanders vision, only a small piece that pertains to them.”

An analysis of criterion and construct validity was performed to examine the relationship between the measure and other variables. The analysis of criterion validity was conducted using a bivariate correlation between the mean score of all items on the measure and a rating of the target Soldier's overall effectiveness asked at the end of the questionnaire. The target Soldier's effectiveness was rated on a 7-point scale from very ineffective to very effective. Results indicated that the mean score of all initiative items was strongly correlated with the target Soldier's overall effectiveness, producing a validity coefficient of, $r=0.87, p<.001$. This provides support for the measure's criterion validity.

The analysis of construct validity was conducted using a bivariate correlation between the mean score of all items on the measure and a "display of initiative" measure asked at the end of the questionnaire. The display of initiative was measured with the item: "In performing this difficult work related task, mission, or assignment, the Soldier displayed initiative.” The target Soldier was rated on a 7-point scale from strongly disagree to strongly agree. Results indicated that the mean score of all initiative items was strongly correlated with the display of initiative, producing a validity coefficient of, $r=0.89, p<.001$, thereby providing additional support for the measure’s construct validity.

Perseverance. The following descriptive statistics describe the item functionality. The range for all of the items in the perseverance measure was 6, indicating that Soldiers used all of the response options on the bipolar response scale. The means for these items ranged from 4.36 to 5.03, suggesting that the item means were not skewed positively or negatively. Lastly, the standard deviations for the items on the initiative measure ranged from 1.86 to 2.34, which indicate adequate variance in the respondent ratings across all of the items.

The PCA conducted with the perseverance data revealed only one component with an eigen value greater than 1 (14.01). Inspection of the scree plot also revealed a steep break after the first component (see Figure 2). Finally, all 18 items loaded onto the first component with component loadings greater than .7. This provided strong evidence for retaining all 18 items in one measure of perseverance. This component appears to be a measure of general motivation or desire to achieve, attain goals, and win in spite of setbacks and obstacles. A positive outlook or disposition is associated with this construct. It also reflects the ability to effectively handle setbacks and creatively find ways to attain goals and objectives. 


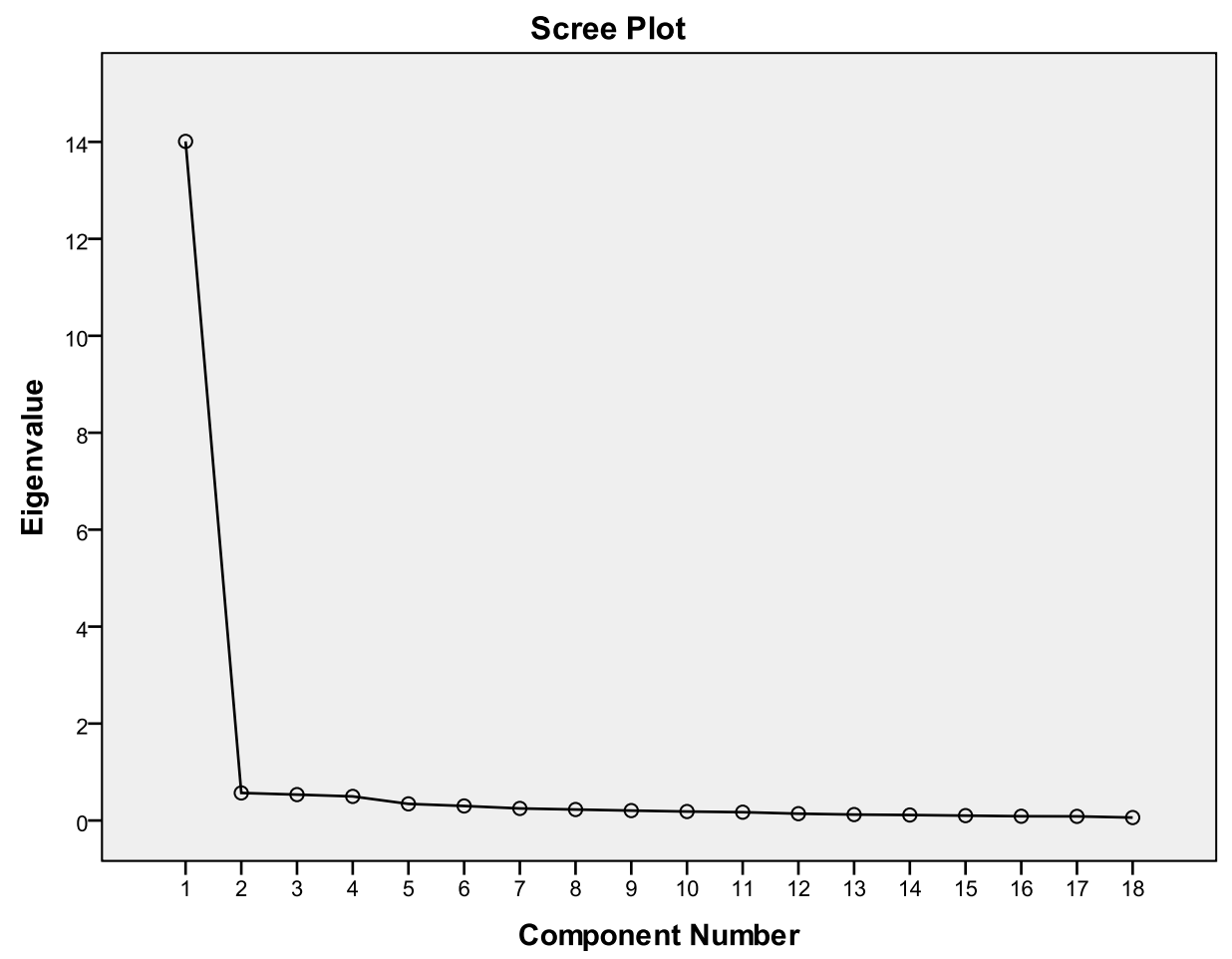

Figure 2. Scree plot depicting the eigen values for each component resulting from a principal component analysis of the 18 perseverance items.

Overall, the measure demonstrated strong internal consistency $(\alpha=0.98)$. Further results indicated that the reliability would not be increased by discarding any of the items. Results of both the PCA and reliability analyses supported retaining all 18 items and provided evidence that all 18 items assessed the same construct, namely perseverance.

As with the initiative measure, Soldiers were asked to respond with their level of agreement to the following item after completing the persistence measure: "The items in this questionnaire were easy to understand.” Results indicated that $82.1 \%$ of Soldiers demonstrated some level of agreement, whereas only $6.4 \%$ demonstrated some level of disagreement. These results suggest that the vast majority of Soldiers found the items in the questionnaire easy to understand which further underlies statistical reliability estimates. When Soldiers were asked to identify items that they thought were unclear, no items were identified.

An analysis of criterion and construct validity was performed to examine the relationship between the measure and other variables. The analysis of criterion validity was conducted using a bivariate correlation between the mean score of all items on the measure and a rating of the target Soldier's overall effectiveness asked at the end of the questionnaire. The target Soldier's effectiveness was rated on a 7-point scale from very ineffective to very effective. Results indicated that the mean score of all perseverance items was strongly correlated with the target Soldier's overall effectiveness, producing a validity coefficient of, $r=0.85, p<.001$, providing support for the measure's criterion validity. 
The analysis of construct validity was conducted using a bivariate correlation between the mean score of all items on the measure and a "display of perseverance" item asked at the end of the questionnaire. The display of perseverance was measured with the item: "In performing this difficult work related task, mission, or assignment, the Soldier displayed perseverance.” The target Soldier was rated on a 7-point scale from strongly disagree to strongly agree. Results indicated that the mean score of all perseverance items was strongly correlated with the display of initiative, producing a validity coefficient of, $r=0.88, p<.001$, thereby providing additional support for the measure's construct validity.

\section{Summary of Analysis for Initiative and Perseverance Measures}

The descriptive statistics suggested that all items on both measures functioned appropriately. The means, standard deviations, and ranges demonstrated that Soldiers were able to use the entire response scale and that there was variance in Soldiers' responses. Items were not skewed to positive or negative for any of the items.

In order to address concerns with the high levels of reliability shown (generally for scales such as these reliabilities are not as high as .98) and to ensure that the analyses were accurate, an additional set of reliability analyses were run as a check on the original data analyses. The results produced the same reliability coefficient. To further explore this situation and ensure the high reliability number was not being skewed by improper data, an invariance analysis was run to determine the amount of invariant responding (a potential sign of non-effortful responding) within the data set. Non-variant responders accounted for roughly $13 \%$ of the original data sets. The removal of non-variant responders did not significantly change the reliability coefficient of either scale (e.g., perseverance and initiative) as both still rounded to a .98.

The high reliabilities shown by each scale could be explainable given certain dynamics are at work. The first explanation could be that due to the thoroughness of the literature review and initial content validation conducted, the items within each measure are highly related to one another and are therefore receiving similar ratings from respondents. Another likely explanation is that due to the focused content domain of each construct (e.g., perseverance and initiative); it is highly likely that a rated Soldier possessing one facet of the construct exhibited other aspects of the construct as well. The noncommissioned officers (NCO) and officers conducting the ratings could also provide and explanation for the high reliabilities. It could be argued that officer and NCO data collection participants were not distinguishing meaningfully between items and more likely rating from a general sense, thus causing high reliability. However, when invariant responding was eliminated from the data set, reliabilities were still high. A cutoff of .21 variance in responding was used at one point as a data check. The reliability was still at .97 for each scale. Thus, responses were varied within participants, but still highly reliable across participants.

The results of the principal components analyses and reliability analyses suggest that both measures consist of one component, and that all 18 items for each should be retained. Initiative appears to be measuring a general action orientation while perseverance appears to evaluate positive disposition to achieve in spite of difficulties. The item functionality suggests that the bipolar response scales were useful in capturing Soldiers' responses. Additionally, the supporting questions also suggested that the items for both measures were easy to understand 
which again underpins statistical calculations of item reliability as well as the utility of the bipolar scales.

Lastly, the criterion-related findings suggested that initiative and perseverance were highly related to performance during difficult work related tasks, missions, and assignments. The strong relationship between the items in each measure and Soldiers' respective overall ratings of initiative and perseverance provided additional support for the construct validity of each measure. Overall, these results provided strong evidence for the construct validity of both measures. These results suggested that the measures were ready for the pilot in Task 2 of this research.

\section{Task 2: Pilot of Assessments}

The purpose of Task 2 was to pilot the measures of initiative and perseverance by administering them to Soldiers participating in situational training exercises (STX) at the Medical Simulation Training Center (MSTC). This training involved assessment, care, and transport of life-like dummies (e.g., 'casualties') through an indoor and outdoor obstacle course. Specifically, it was important to ensure that both measures were viewed as important, of an appropriate length, and included clearly written instructions and items. Soldiers (serving as squad leaders) at MSTC were chosen for the pilot because its training puts Soldiers under conditions in which they are expected to exhibit initiative and perseverance. Furthermore the squad leaders, by way of their Army and supervisory experience, met the rating criteria previously identified to accurately rate intangible constructs (in Soldiers they were already leading).

\section{Participants}

A total of nine experienced squad leaders and one additional Soldier participated in the pilot. Of these 10 Soldiers, nine indicated that their rank was "SGT" and one indicated "Other." Nine of the participants indicated that their position was "Squad/Section/Team Leader" while one indicated "Other NCO Position." The average time of service for the 10 participants was 63.1 months (just over five years) and the average number of deployments was 1.7. Thus, those completing ratings on Soldier intangibles possessed the experience a previous phase of this research indicated was needed to do so.

\section{Measures}

The two 18-item measures administered in the pilot were identical to those in Task 1 , although the format and instructions slightly differed and the evaluation items that followed the measures were expanded and revised (six items plus an open-ended question for additional comments). These adjustments were made to account for the change in use of the measures from thinking about a Soldier and rating him/her, to the actual observation and subsequent rating of that same Soldier. For each of the six evaluation items, participants responded according to a 7-point Likert scale ( 1 = Strongly Disagree, $7=$ Strongly Agree). A copy of the initiative and perseverance measures used in the pilot are provided in Appendix $\mathrm{C}$ and $\mathrm{D}$, respectively. 


\section{Procedure}

The procedure for the pilot involved two main steps. In the first step, squad leaders were oriented to the two measures, privacy act signatures were obtained, and the risks and benefits of this research to them and the Army as a whole were explained. Squad leaders were told to pay particular attention to Soldiers in their squad who exhibited signs of initiative and/or perseverance (or a lack thereof). They were then shown the two measures they would be expected to rate a Soldier on and asked to quickly scan and indicate their understanding of the items. The squad leaders were then reminded that they would rate one Soldier on each construct measure at the conclusion of the MSTC exercise.

In the second step, the squad leaders met back with the research team during the MSTC time period for after action review. During this meeting, they were asked to recall one or more Soldiers who displayed initiative and perseverance (or a lack of these behaviors) during the MSTC exercises. Each participant was then provided with instructions for the two measures, and asked to rate one Soldier using the initiative measure and either the same or a different Soldier using the perseverance measure. Soldiers were also instructed to complete the brief evaluation (six items and one open-ended question) for each measure. After completing both measures and the evaluations, squad leaders were thanked for their participation and contribution to Army understanding of Soldier perseverance and initiative.

\section{Results}

The focus of the pilot data analysis was on the initiative and perseverance measure evaluation items and open-ended question that participants completed after having rated Soldier intangibles. These items were designed to confirm the presence of the intangible during the training exercise and obtain user feedback on the effective use of the measures in a field environment. The means and standard deviations for these six items, for initiative and perseverance, are provided in Table 3.

The results presented in Table 3 provide support for the both the appropriateness of the training venue selected for the pilot as well as the effective field use of the two measures. The MSTC training venue clearly provided the opportunity for Soldiers to display initiative and perseverance. Furthermore, while previous research had indicated that the content comprising these two constructs was important, it was good confirmation that both of the named constructs, initiative and perseverance, were viewed by these 10 NCO's as an important aspect of training (Mean $=6.60$ out of a 7.0 scale). The squad leaders tended to disagree with the statement "there were too many questions in this measure" confirming that the 18 item length was about right. Ease of understanding of measure instructions and the items themselves was also a positive finding. 
Table 3.

Means and Standard Deviations for Four Evaluation Items for Initiative and Perseverance Measures

\begin{tabular}{|c|c|c|c|c|}
\hline & Initiative & & erance & \\
\hline Item & Mean & SD & Mean & SD \\
\hline $\begin{array}{l}\text { During this training event the Soldier I rated } \\
\text { displayed ___ }\end{array}$ & 5.40 & 1.96 & 6.40 & 1.58 \\
\hline $\begin{array}{l}\text { The Soldier I rated was effective overall in this training } \\
\text { event. }\end{array}$ & 5.80 & 1.14 & 6.00 & 0.82 \\
\hline This measure concerns an important aspect of training. & 6.60 & 0.70 & 6.60 & 0.70 \\
\hline There were too many questions in this measure. & 3.10 & 1.45 & 3.40 & 1.17 \\
\hline $\begin{array}{l}\text { The instructions for this measure were easy to } \\
\text { understand. }\end{array}$ & 6.30 & 1.57 & 6.50 & 0.97 \\
\hline The items in this measure were easy to understand. & 6.80 & 0.42 & 6.80 & 0.42 \\
\hline
\end{tabular}

Note: 7-point Likert scale ranging from strongly disagree (1) to strongly agree (7)

In responding to an open-ended question that inquired about any additional comments on the measures, few of the squad leaders had anything to say. One participant suggested that the measures ought to be used by leaders with their own platoons and squads. At the MSTC, participants come from a variety of Fort Hood units and squad leaders are designated for the purpose of preparation and supervisory support during the MSTC. This participant went on to say that a leader who knows his Soldiers very well could use the measures more effectively as a tool. This comment lends support for one of the primary uses of the measures to be by the actual supervisors of Soldiers. Other verbal or write in comments were either unrelated to the importance, usability, or clarity of the measures, or supported them as currently constructed.

\section{Discussion}

This study provided strong support for the construct validity of the initiative and perseverance measures. In conducting Task 1, strong statistical support was found for retaining 18-item measures for both initiative and perseverance. Results of principal component analyses indicated that for each measure, all 18 items loaded onto one component, respectively. While initiative appears to be measuring an overall action orientation, perseverance is measuring a motivation to achieve in spite of obstacles and setbacks. This suggests that it was effective to assess each of the constructs with a separate 18-item measure, no subscales were necessary, and that each measure appears to be assessing one general construct. These findings are consistent with previous content validation which came up with one set of items for each construct, without subscales. Additionally, the use of bipolar response scales was effective at avoiding common measurement problems such as response range restriction, skewness, and a lack of variability in 
responses. Bipolar scales also contributed to ease of use by raters. Furthermore, reliability analyses (internal consistency, as measured by Cronbach's alpha) provided additional support for retaining all 18 items in the scales. These analyses indicated that all 18 items were strongly interrelated and that alpha did not increase for either measure by deleting any items, suggesting it was best to retain all 18 items in both measures.

This study also found support for the field utility of the instruments for measuring intangibles during realistic training. Findings from the Task 2 pilot indicated that squad leaders who completed the measures felt that they assessed an important aspect of training, that the measures did not include too many items, and that instructions and items themselves were clear. These pilot findings confirm the general face validity of the two measures and that they represent constructs important to Soldier mission readiness.

\section{Future Research}

The current research provides valid and reliable measures of Soldier initiative and perseverance. Yet, beyond providing Soldiers or their leaders with a scaled rating of each construct, there are no suggestions or recommendations as to how a Soldier who is rated low, for example, might improve. Earlier phases of this research identified the type of training within which the intangible constructs are best observed and experienced. Yet, the mere experience of situations requiring the display of initiative and/or perseverance are not known to, in and of themselves, improve a Soldier's display of either intangible. Specific types of training or targeted tasks (e.g., confidence building exercises) might prove helpful toward the development of initiative and perseverance. While it is beyond the scope of this research to identify means of intangible development, future research might focus on some of the following ideas.

It may be the case that the mere administration and use of appropriate feedback methods with Soldiers would make them more aware of the behavioral indicators of initiative and perseverance. Consequently, feedback on their ratings may lead to greater exhibition and demonstration of behaviors associated with initiative and perseverance. So, too, a leader's use of reinforcement (e.g., praise, encouragement) associated with the behaviors hold promise for increasing the frequency of their occurrence in Soldiers.

Then again, it may be that initiative and perseverance are more trait-like and not easily subject to development and change. In other words, initiative and perseverance may be human characteristics or dispositions that are fixed early in life. Consequently, it would be difficult for a Soldier, or those who supervise them, to change the level of initiative or perseverance an individual exhibits during a single unit assignment. Thus, research that determines the extent to which the intangibles are fixed, learned over time, or subject to immediate change and development, would be helpful toward shaping unit level interventions and expectations. Specifically, it would help Soldiers and their leaders to know to what degree they can and should expect these intangibles to change over time. Additionally, such research might also lead to the use of perseverance and initiative measures as key measures for job selection. The U.S. Army Research Institute has an extensive history, and an active program of research, in conducting selection and assessment upon which the measures described in this report could be linked (e.g., Allen \& Young, 2012; Knapp, Sager, \& Tremble, 2005; Maier \& Fuchs, 1969; Zook, 1996). 
Lastly, it would be helpful to engage Army leaders in a discussion of the potential applications of this research. For example, conducting a working session with senior unit leaders, training officers and NCOs, to identify where and how the measures ought to be used, would be an important next step. Such a session might also guide and focus the future research agenda herein. 


\section{References}

Allen, M. T., \& Young, M. C. (2012). Longitudinal Validation of Non-Cognitive Officer Selection Measures for the U.S. Army Officer Candidate School (OCS). (Technical Report 1323). Fort Belvoir, VA: U.S. Army Research Institute for the Behavioral and Social Sciences.

Aude, S. N., Bryson, J., Keller-Glaze, H., Nicely, K., \& Vowels, C. L. (2014). Preparing Brigade Combat Team (BCT) Soldiers for mission readiness through research on intangible psychological constructs and their applications. (Technical Report 1336). Fort Belvoir, VA: U.S. Army Research Institute for the Behavioral and Social Sciences.

Aude, S. N., Keller-Glaze, H., Nicely, K., Shuffler, M., \& Vowels, C. L. (2014). Preparing Brigade Combat Team (BCT) Soldiers for mission readiness through research on intangible psychological constructs and their applications: Measurement and learning methods. (Technical Report 1333). Fort Belvoir, VA: U.S. Army Research Institute for the Behavioral and Social Sciences.

Knapp, D. J., Sager, C. E., \& Tremble, T. R. (2005). Development of Experimental Army Enlisted Personnel Selection and Classification Tests and Job Performance Criteria. (Technical Report 1168). Arlington, VA: U.S. Army Research Institute for the Behavioral and Social Sciences.

Krosnick, J. A. \& Tahk, A. (n.d.) The optimal length of rating scales to maximize reliability and validity. Retrieved January 3, 2012 from http://comm.stanford.edu/faculty/krosnick/

Maier, M. H., \& Fuchs, E. F. (1969). Development of Improved Aptitude Area Composites for Enlisted Classification. (Technical Research Report 1159). Arlington, VA: U.S. Army Research Institute for the Behavioral and Social Sciences.

Spreitzer, G. M., McCall, M. W., Jr., \& Mahoney, J. D. (1997). Early identification of international executive potential. Journal of Applied Psychology, 83, 6-29.

Zook, L. M. (1996). Soldier Selection: Past, Present, and Future. (Special Report 28). Alexandria, VA: U.S. Army Research Institute for the Behavioral and Social Sciences. 
Appendix A

Initiative Measure - Task 1 


\section{Measuring Intangible Attributes Questionnaire}

Instructions - Think of a Soldier (E5-O6) whom you recently observed going through a difficult work related task, mission, or assignment that required the Soldier to act using his/her own discretion, independently of outside influence or control. The items in this questionnaire describe behaviors. For each item, first read the behavior on the left and the behavior on the right. Then, circle the rating between 1 and 7 that best represents the degree to which the Soldier resembled the behavior on the left or right while performing the difficult work related task, mission or assignment. For example, if after reading the behaviors on the left and right for item 1, you feel the Soldier's behavior was almost identical to the behavior on the left, you would circle " 1 " in that row.

Before continuing with the questionnaire, please indicate the rank of the Soldier you will base your ratings upon:

In the space below, briefly describe the event you are basing your ratings on. Do not use personally identifying information.

\begin{tabular}{|c|c|c|c|c|c|c|c|c|c|c|}
\hline 1. & $\begin{array}{l}\text { Required detailed orders and a lot of } \\
\text { inspiration from leaders to accomplish tasks }\end{array}$ & 1 & 2 & 3 & 4 & 5 & 6 & 7 & Nobs & $\begin{array}{l}\text { Demonstrated the ability to self-start, push } \\
\text { self, and be proactive in accomplishing tasks }\end{array}$ \\
\hline 2. & Did the bare minimum & 1 & 2 & 3 & 4 & 5 & 6 & 7 & Nobs & Took every opportunity to be involved \\
\hline 3. & $\begin{array}{l}\text { Waited too long or failed to act to } \\
\text { accomplish the mission due to incomplete or } \\
\text { imperfect information }\end{array}$ & 1 & 2 & 3 & 4 & 5 & 6 & 7 & Nobs & $\begin{array}{l}\text { Effectively acted on incomplete or imperfect } \\
\text { information to accomplish the mission }\end{array}$ \\
\hline 4. & Put off or avoided looming problems & 1 & 2 & 3 & 4 & 5 & 6 & 7 & Nobs & Actively attacked problems \\
\hline 5. & $\begin{array}{l}\text { Failed to rise to challenges when it mattered } \\
\text { most }\end{array}$ & 1 & 2 & 3 & 4 & 5 & 6 & 7 & Nobs & $\begin{array}{l}\text { Stepped up and took on more when it } \\
\text { mattered most }\end{array}$ \\
\hline
\end{tabular}




\begin{tabular}{|c|c|c|c|c|c|c|c|c|c|c|}
\hline & & 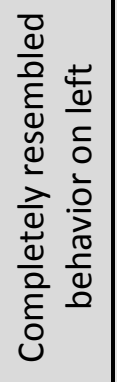 & 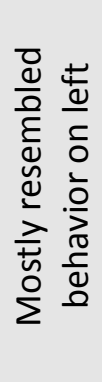 & 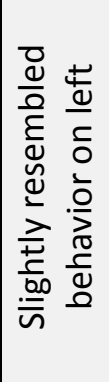 & 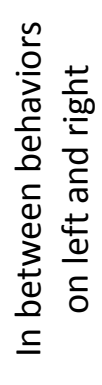 & 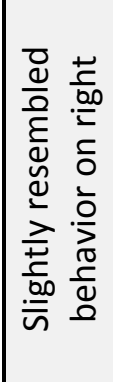 & 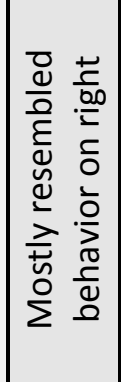 & 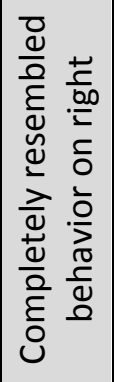 & 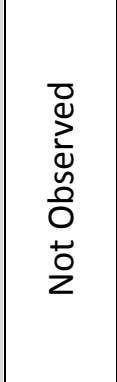 & \\
\hline 6. & $\begin{array}{l}\text { Hesitated to step up even when those } \\
\text { around were doing so }\end{array}$ & 1 & 2 & 3 & 4 & 5 & 6 & 7 & Nobs & $\begin{array}{l}\text { Took initiative immediately even when } \\
\text { others didn't }\end{array}$ \\
\hline 7. & $\begin{array}{l}\text { Focused solely on their own performance } \\
\text { and did not challenge nor develop peers and } \\
\text { subordinates }\end{array}$ & 1 & 2 & 3 & 4 & 5 & 6 & 7 & Nobs & $\begin{array}{l}\text { Trained, motivated, and encouraged peers } \\
\text { and subordinates through challenges and } \\
\text { difficulty }\end{array}$ \\
\hline 8. & $\begin{array}{l}\text { Did not see the next steps and required } \\
\text { orders to proceed through tasks to } \\
\text { accomplish the mission }\end{array}$ & 1 & 2 & 3 & 4 & 5 & 6 & 7 & Nobs & $\begin{array}{l}\text { Prepared for the next step and works ahead } \\
\text { to complete the mission }\end{array}$ \\
\hline 9. & $\begin{array}{l}\text { Complained excessively when executing } \\
\text { orders and mission tasks }\end{array}$ & 1 & 2 & 3 & 4 & 5 & 6 & 7 & Nobs & $\begin{array}{l}\text { Diligently executed orders and mission tasks } \\
\text { with enthusiasm }\end{array}$ \\
\hline 10. & $\begin{array}{l}\text { Could only handle immediate tasks and did } \\
\text { not think ahead to see potential problems or } \\
\text { barriers to mission accomplishment }\end{array}$ & 1 & 2 & 3 & 4 & 5 & 6 & 7 & Nobs & $\begin{array}{l}\text { Anticipated problems or barriers to mission } \\
\text { accomplishment }\end{array}$ \\
\hline 11. & $\begin{array}{l}\text { Only took on simple tasks that came easy to } \\
\text { him or her }\end{array}$ & 1 & 2 & 3 & 4 & 5 & 6 & 7 & Nobs & $\begin{array}{l}\text { Took on unpleasant/difficult tasks that may } \\
\text { not have come easily to him or her }\end{array}$ \\
\hline 12. & $\begin{array}{l}\text { Avoided lead role and additional } \\
\text { responsibility }\end{array}$ & 1 & 2 & 3 & 4 & 5 & 6 & 7 & Nobs & Took ownership of the mission \\
\hline 13. & $\begin{array}{l}\text { Did not attempt to identify the tasks that } \\
\text { needed to be done to accomplish the } \\
\text { mission on their own }\end{array}$ & 1 & 2 & 3 & 4 & 5 & 6 & 7 & Nobs & $\begin{array}{l}\text { Identified the tasks that needed to be done } \\
\text { to accomplish the mission on their own }\end{array}$ \\
\hline 14. & $\begin{array}{l}\text { Made excuses for poor performance and did } \\
\text { not learn from experience or mistakes }\end{array}$ & 1 & 2 & 3 & 4 & 5 & 6 & 7 & Nobs & Treated experiences as development \\
\hline
\end{tabular}




\begin{tabular}{|c|c|c|c|c|c|c|c|c|c|c|}
\hline & & 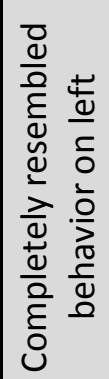 & 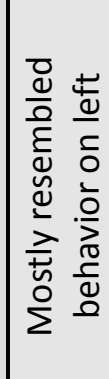 & 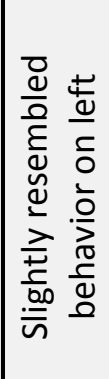 & 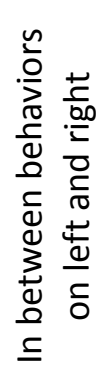 & 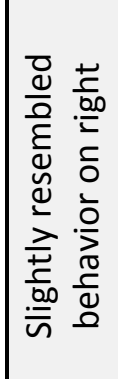 & 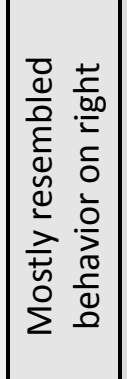 & 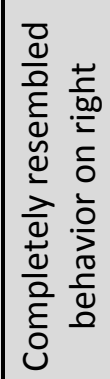 & 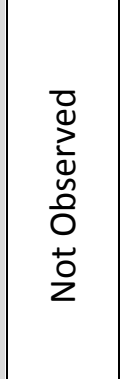 & \\
\hline 15. & Was lazy and/or wasted spare time & 1 & 2 & 3 & 4 & 5 & 6 & 7 & Nobs & Utilized spare time effectively \\
\hline 16. & $\begin{array}{l}\text { Failed to listen effectively and mistranslated } \\
\text { commander's vision and intent to } \\
\text { accomplish the mission }\end{array}$ & 1 & 2 & 3 & 4 & 5 & 6 & 7 & Nobs & $\begin{array}{l}\text { Actively listened to and translated } \\
\text { commander's vision and intent to } \\
\text { accomplish the mission. }\end{array}$ \\
\hline 17. & $\begin{array}{l}\text { Shirked responsibility and leadership } \\
\text { positions }\end{array}$ & 1 & 2 & 3 & 4 & 5 & 6 & 7 & Nobs & $\begin{array}{l}\text { When the opportunity arose he or she } \\
\text { assumed leadership positions }\end{array}$ \\
\hline 18. & $\begin{array}{l}\text { Acted only when ordered to do so and failed } \\
\text { to adapt the intent of an order when } \\
\text { necessary }\end{array}$ & 1 & 2 & 3 & 4 & 5 & 6 & 7 & Nobs & $\begin{array}{l}\text { Acted in the absence of orders, when } \\
\text { existing orders no longer fit the situation, or } \\
\text { when unforeseen opportunities or threats } \\
\text { arose }\end{array}$ \\
\hline
\end{tabular}




\section{Follow-Up Questions}

1. Rate the Soldier's overall effectiveness at the difficult work related task, mission or assignment. (Circle one option below)

\begin{tabular}{|c|c|c|c|c|}
\hline $\begin{array}{c}\text { Very } \\
\text { Ineffective }\end{array}$ & Ineffective & $\begin{array}{l}\text { Somewhat } \\
\text { Ineffective }\end{array}$ & $\begin{array}{c}\text { Neither } \\
\text { Effective/Ineffective }\end{array}$ & Effective \\
\hline
\end{tabular}

Very Effective

Indicate the degree to which you agree with the statements below.

2. In performing this difficult work related task, mission or assignment, the Soldier displayed initiative. (Circle one option below)

\begin{tabular}{|c|c|c|c|}
\hline $\begin{array}{l}\text { Strongly } \\
\text { Disagree }\end{array}$ & Disagree & $\begin{array}{c}\text { Somewhat } \\
\text { Disagree }\end{array}$ & $\begin{array}{c}\text { Neither } \\
\text { Agree Nor Disagree }\end{array}$ \\
\hline
\end{tabular}

Agree

Strongly

Disagree Disagree

Agree Nor Disagree

Agree

Agree

3. The items in this questionnaire were easy to understand. (Circle one option below)

$\begin{array}{lccccc}\text { Strongly } & \text { Disagree } & \text { Somewhat } & \text { Neither } & \text { Somewhat } & \text { Agree } \\ \text { Disagree } & & \text { Disagree } & \text { Agree Nor Disagree } & \text { Agree } & \text { Strongly } \\ \text { Agree }\end{array}$

If any of the items were unclear, please list the item numbers 
Appendix B

Perseverance Measure - Task 1 


\section{Measuring Intangible Attributes Questionnaire}

Instructions - Think of a Soldier (E5-O6) whom you recently observed going through a difficult work related task, mission or assignment that required effort to do or achieve something despite difficulties, failure, or opposition. The items in this questionnaire describe behaviors. For each item, first read the behavior on the left and the behavior on the right. Then, circle the rating between 1 and 7 that best represents the degree to which the Soldier resembled the behavior on the left or right while performing the difficult work related task, mission or assignment. For example, if after reading the behaviors on the left and right for item 1, you feel the Soldier's behavior was almost identical to the behavior on the left, you would circle " 1 " in that row.

Before continuing with the questionnaire, please indicate the rank of the Soldier you will base your ratings upon:

\begin{tabular}{|c|c|c|c|c|c|c|c|c|c|c|}
\hline & \multirow{2}{*}{$\begin{array}{l}\text { In the space below, briefly describe the } \\
\text { event you are basing your ratings on. } \\
\text { Do not use personally identifying } \\
\text { information. }\end{array}$} & \multicolumn{8}{|c|}{ Response Options (circle one for each row) } & \\
\hline & & 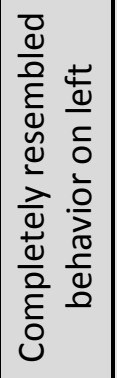 & 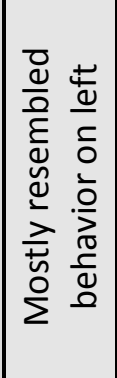 & 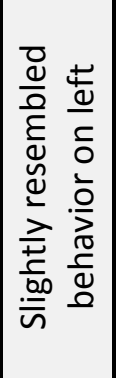 & 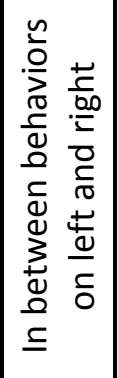 & 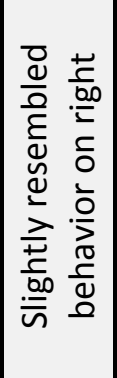 & 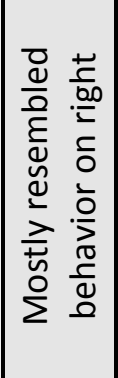 & 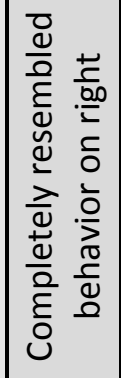 & 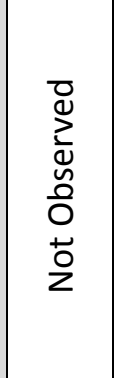 & \\
\hline 1. & Lacked mental toughness & 1 & 2 & 3 & 4 & 5 & 6 & 7 & Nobs & Demonstrated mental toughness \\
\hline 2. & Reacted negatively to criticism & 1 & 2 & 3 & 4 & 5 & 6 & 7 & Nobs & Accepted criticism \\
\hline 3. & $\begin{array}{l}\text { Demonstrated insubordination and fell } \\
\text { short of Army professional ethic and } \\
\text { standards }\end{array}$ & 1 & 2 & 3 & 4 & 5 & 6 & 7 & Nobs & $\begin{array}{l}\text { Impeccably demonstrated discipline } \\
\text { and Army professional ethic }\end{array}$ \\
\hline 4. & Could not find positives in a bad situation & 1 & 2 & 3 & 4 & 5 & 6 & 7 & Nobs & Found good in a bad situation \\
\hline 5. & $\begin{array}{l}\text { Gave up easily when facing obstacles, } \\
\text { barriers, and adversity }\end{array}$ & 1 & 2 & 3 & 4 & 5 & 6 & 7 & Nobs & $\begin{array}{l}\text { Persisted in the face of obstacles, } \\
\text { barriers, and adversity }\end{array}$ \\
\hline
\end{tabular}




\begin{tabular}{|c|c|c|c|c|c|c|c|c|c|c|}
\hline & & 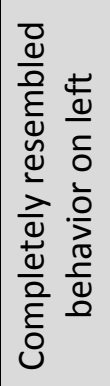 & 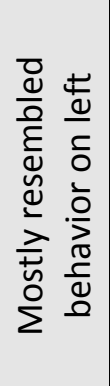 & 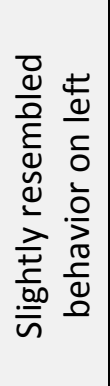 & 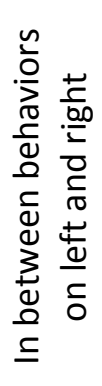 & 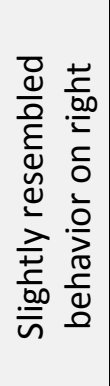 & 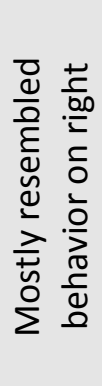 & 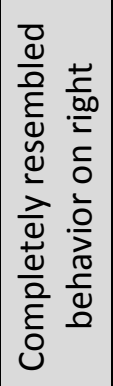 & 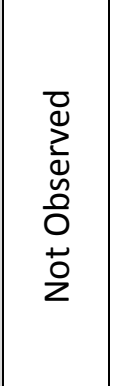 & \\
\hline 6. & $\begin{array}{l}\text { Was easily discouraged and allowed } \\
\text { setbacks to negatively affect mission } \\
\text { accomplishment }\end{array}$ & 1 & 2 & 3 & 4 & 5 & 6 & 7 & Nobs & $\begin{array}{l}\text { Did not get discouraged and } \\
\text { overcame setbacks }\end{array}$ \\
\hline 7. & $\begin{array}{l}\text { Demonstrated a lack of enthusiasm or } \\
\text { indifference to individual and unit } \\
\text { success }\end{array}$ & 1 & 2 & 3 & 4 & 5 & 6 & 7 & Nobs & $\begin{array}{l}\text { Demonstrated a competitive spirit } \\
\text { and will to win }\end{array}$ \\
\hline 8. & $\begin{array}{l}\text { Frequently quit and failed to finish what } \\
\text { he or she started }\end{array}$ & 1 & 2 & 3 & 4 & 5 & 6 & 7 & Nobs & $\begin{array}{l}\text { Never quit nor accepted defeat; } \\
\text { finished what they begin }\end{array}$ \\
\hline 9. & $\begin{array}{l}\text { Became overwhelmed easily and failed } \\
\text { when facing difficult challenges }\end{array}$ & 1 & 2 & 3 & 4 & 5 & 6 & 7 & Nobs & $\begin{array}{l}\text { Didn't get overwhelmed by problems } \\
\text { or challenges and thrived under } \\
\text { these constraints }\end{array}$ \\
\hline 10. & Was unconcerned with improvement & 1 & 2 & 3 & 4 & 5 & 6 & 7 & Nobs & $\begin{array}{l}\text { Always did troubleshooting and tried } \\
\text { to improve }\end{array}$ \\
\hline 11. & $\begin{array}{l}\text { When told he or she couldn't do } \\
\text { something, his or her effort decreased } \\
\text { and he or she was less likely to try again }\end{array}$ & 1 & 2 & 3 & 4 & 5 & 6 & 7 & Nobs & $\begin{array}{l}\text { When told he or she couldn't do } \\
\text { something, he or she got up, doubled } \\
\text { his or her effort, and tried it again }\end{array}$ \\
\hline 12. & $\begin{array}{l}\text { Avoided action or performed poorly } \\
\text { under pressure and stress }\end{array}$ & 1 & 2 & 3 & 4 & 5 & 6 & 7 & Nobs & $\begin{array}{l}\text { Reacted to and remained calm under } \\
\text { pressure and stress }\end{array}$ \\
\hline 13. & Demonstrated a poor work ethic & 1 & 2 & 3 & 4 & 5 & 6 & 7 & Nobs & Demonstrated a strong work ethic \\
\hline 14. & Lacked physical toughness and stamina & 1 & 2 & 3 & 4 & 5 & 6 & 7 & Nobs & $\begin{array}{l}\text { Demonstrated physical toughness } \\
\text { and stamina }\end{array}$ \\
\hline
\end{tabular}




\begin{tabular}{|c|c|c|c|c|c|c|c|c|c|c|}
\hline & & 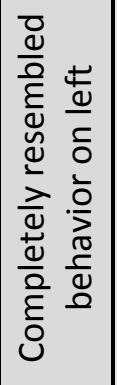 & 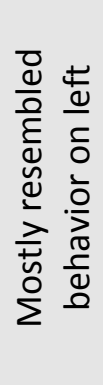 & 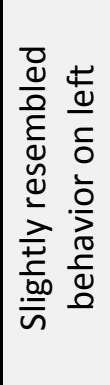 & 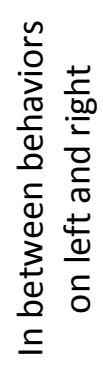 & 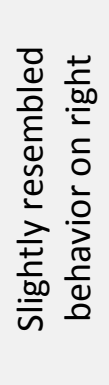 & 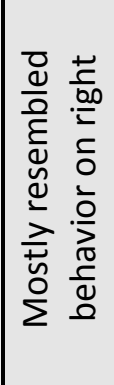 & 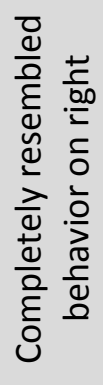 & 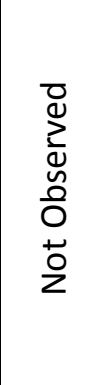 & \\
\hline 15. & $\begin{array}{l}\text { Allowed conditions to cloud ethical } \\
\text { judgment }\end{array}$ & 1 & 2 & 3 & 4 & 5 & 6 & 7 & Nobs & $\begin{array}{l}\text { Did what was right no matter what } \\
\text { the conditions }\end{array}$ \\
\hline 16. & Quit when challenged physically & 1 & 2 & 3 & 4 & 5 & 6 & 7 & Nobs & $\begin{array}{l}\text { Kept going, even when exhausted, } \\
\text { hungry, afraid, cold, and wet }\end{array}$ \\
\hline 17. & Always placed themselves first & 1 & 2 & 3 & 4 & 5 & 6 & 7 & Nobs & Always placed the mission first \\
\hline 18. & $\begin{array}{l}\text { Never did more than he or she was asked } \\
\text { to do and never exceeded expectations }\end{array}$ & 1 & 2 & 3 & 4 & 5 & 6 & 7 & Nobs & $\begin{array}{l}\text { Went above and beyond } \\
\text { expectations and did more than he } \\
\text { or she was asked to do }\end{array}$ \\
\hline
\end{tabular}




\section{Follow-Up Questions}

1. Rate the Soldier's overall effectiveness at the difficult work related task, mission or assignment. (Circle one option below)

\begin{tabular}{|c|c|c|c|c|}
\hline $\begin{array}{c}\text { Very } \\
\text { Ineffective }\end{array}$ & Ineffective & $\begin{array}{l}\text { Somewhat } \\
\text { Ineffective }\end{array}$ & $\begin{array}{c}\text { Neither } \\
\text { Effective/Ineffective }\end{array}$ & $\begin{array}{l}\text { Somewhat } \\
\text { Effective }\end{array}$ \\
\hline
\end{tabular}

Very Effective

Indicate the degree to which you agree with the statements below.

2. In performing this difficult work related task, mission or assignment, the Soldier displayed perseverance. (Circle one option below)

$\begin{array}{lccccc}\text { Strongly } & \text { Disagree } & \text { Somewhat } & \text { Neither } & \text { Somewhat } & \text { Agree } \\ \text { Disagree } & & \text { Disagree } & \text { Agree Nor Disagree } & \text { Agree } & \text { Strongly } \\ \text { Agree }\end{array}$

3. The items in this questionnaire were easy to understand. (Circle one option below)

$\begin{array}{lccccc}\text { Strongly } & \text { Disagree } & \text { Somewhat } & \text { Neither } & \text { Somewhat } & \text { Agree } \\ \text { Disagree } & & \text { Disagree } & \text { Agree Nor Disagree } & \text { Agree } & \text { Strongly } \\ \text { Agree }\end{array}$

If any of the items were unclear, please list the item numbers 
Appendix C

Initiative Measure - Task 2 


\section{Initiative}

\section{Measure}

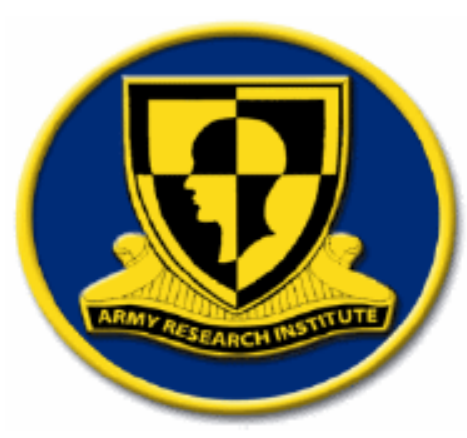

About this Measure: Soldiers have identified initiative as critical to Soldier mission readiness. This measure was designed to be used in field training environments where Soldier's initiative is likely on display (e.g., field training events or CTC rotations). This measure was designed to be used by superior raters or objective raters (e.g., trainer mentors). 


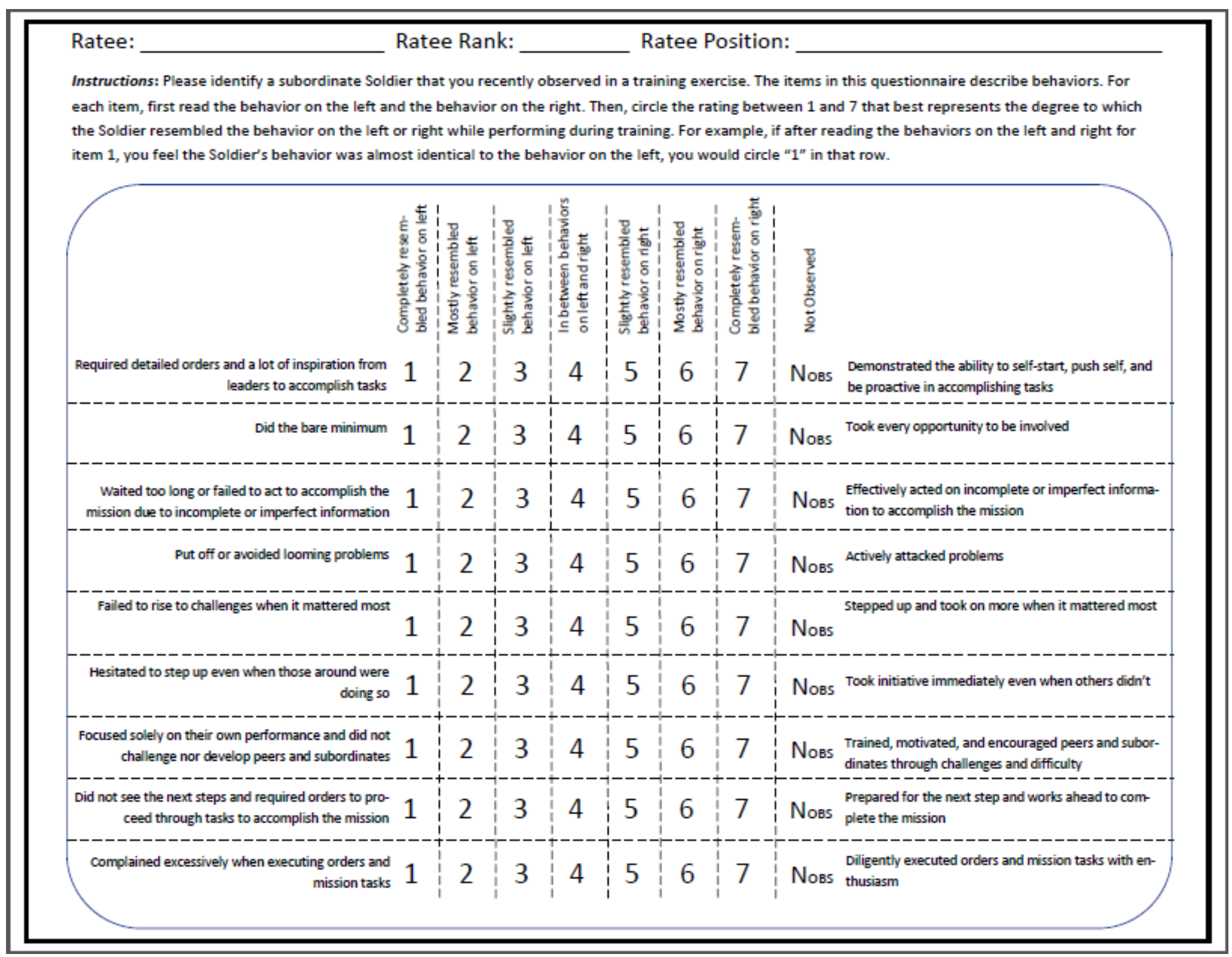


Instructions: Please identify a subordinate Soldier that you recently observed in a training exercise. The items in this questionnaire describe behaviors. For each item, first read the behavior on the left and the behavior on the right. Then, circle the rating between 1 and 7 that best represents the degree to which the Soldier resembled the behavior on the left or right while performing during training. For example, if after reading the behaviors on the left and right for item 1, you feel the Soldier's behavior was almost identical to the behavior on the left, you would circle "1" in that row.

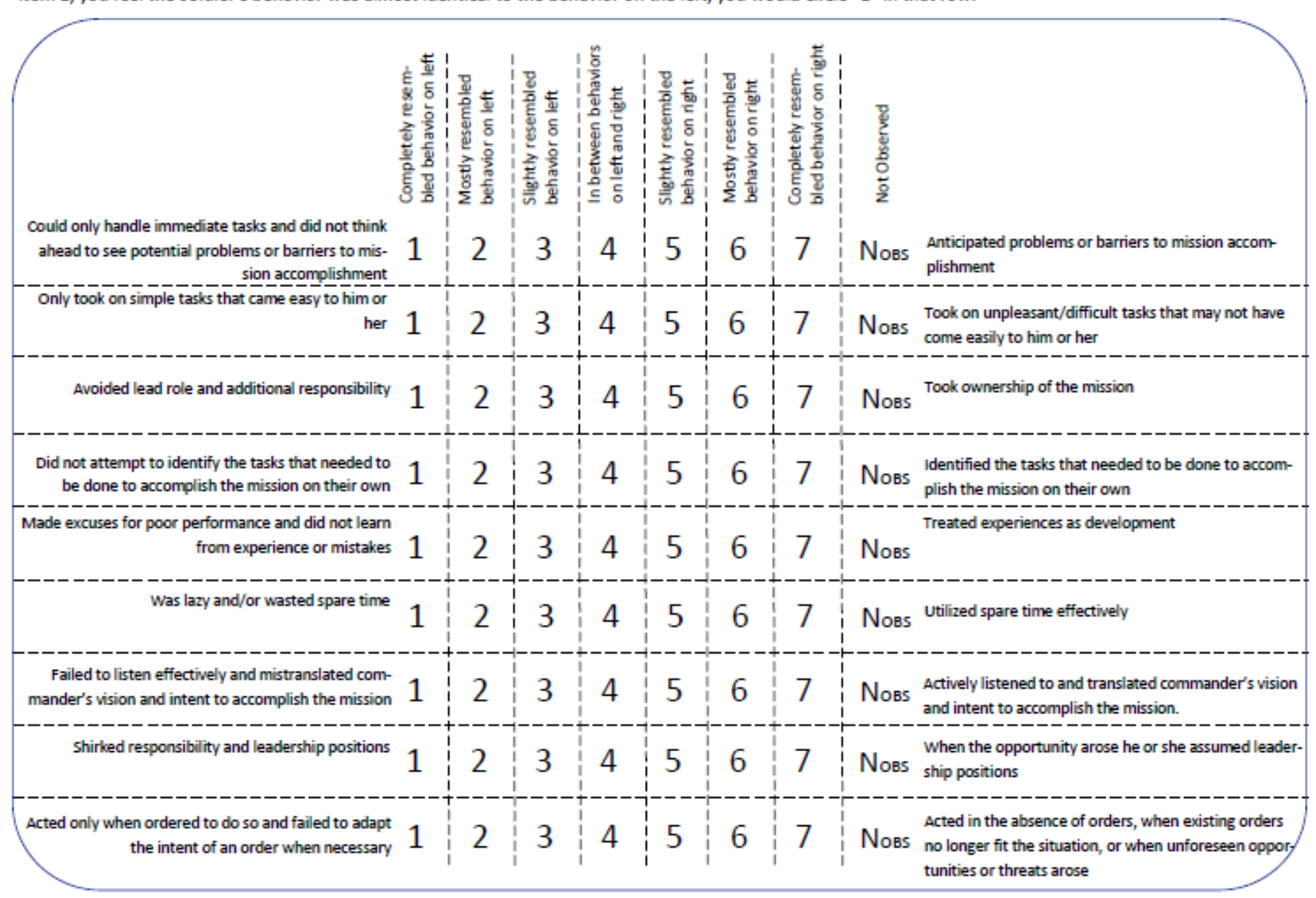




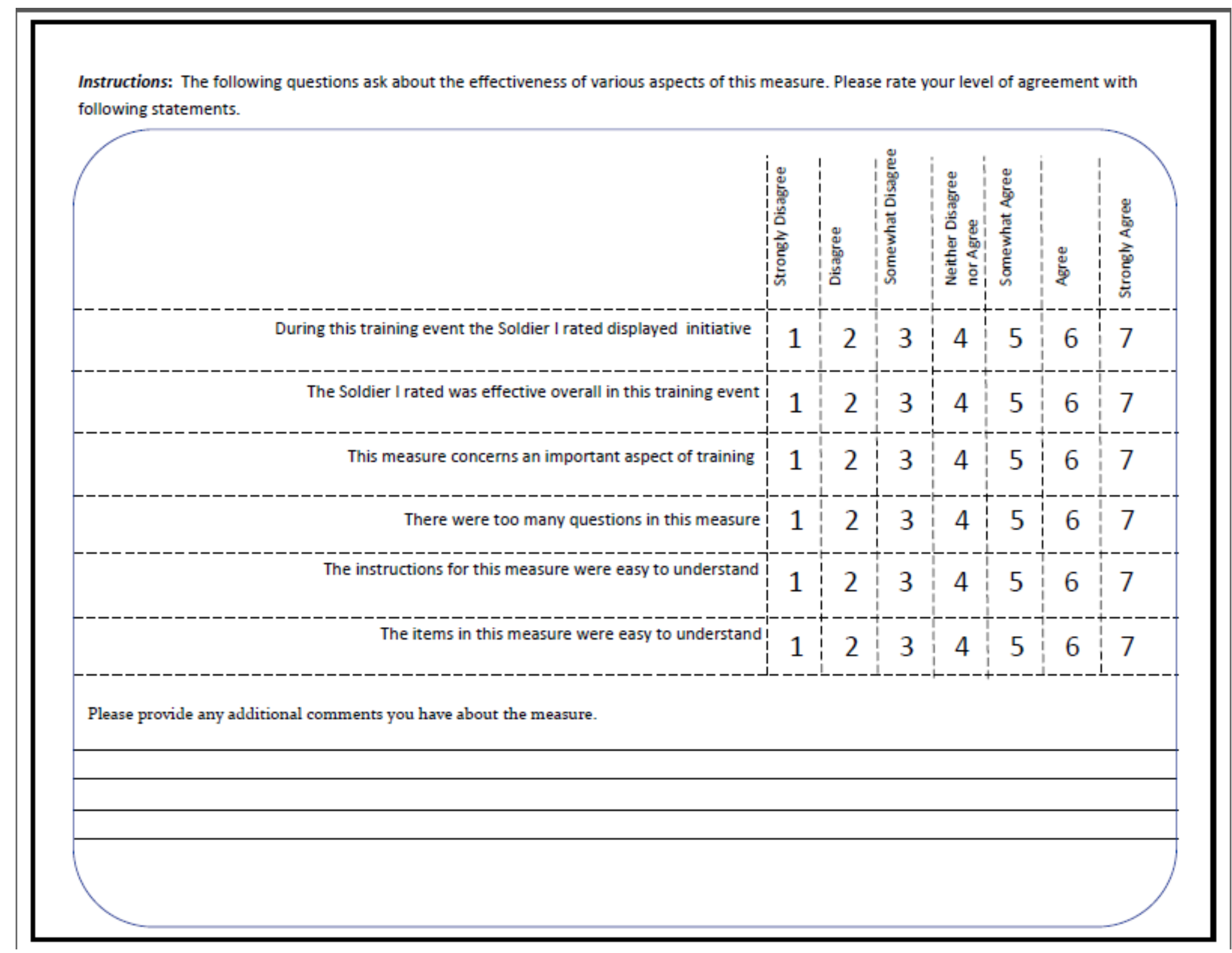


Interpretation: This measure was designed to evaluate a Soldier's initiative in a field setting. The following considerations are important for improving measurement, accuracy, and the interpretation of results.

First, the number 4 serves as a midpoint in the scale of initiative. Therefore, anything above 4 could be seen as above average on initiative and anything below 4 could be seen as below average.

Second, multiple administrations of the measure will improve its accuracy. Further, multiple administrations will allow for comparison of a Soldier's performance in various training environments.

Third, if a Soldier is rated alongside his/her peers in a training event, the ratings can be compared to his/her peers. Further, Soldiers' scores can be examined together to give a picture of initiative within a group (e.g., team, squad).

Lastly, initiative measures can be used to provide some feedback on the effectiveness of training events. For example, if many of the behaviors on the initiative measure are not observed, the training event can be examined and redesigned to provide more opportunities for Soldiers to display initiative.

Providing Feedback: Feedback should be given on an individual basis in developmental counseling sessions. Initiative strengths should be discussed along with weaknesses. In the sessions those providing feedback should help Soldiers to identify tangible behaviors and goals for improvement. 
Appendix D

Perseverance Measure - Task 2 


\section{Perseverance}

\section{Measure}

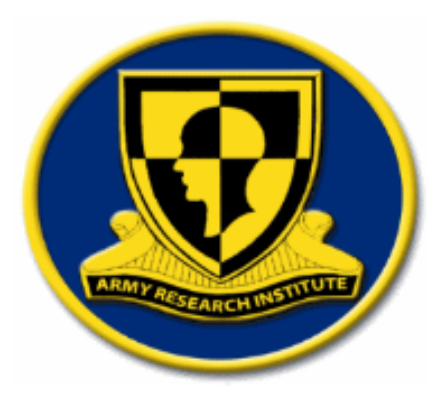

About this Measure: Soldiers have identified perseverance as critical to Soldier mission readiness. This measure was designed to be used in field training environments where Soldier's perseverance is likely on display (e.g., field training events or CTC rotations). This measure was designed to be used by superior raters or objective raters (e.g., trainer mentors). 


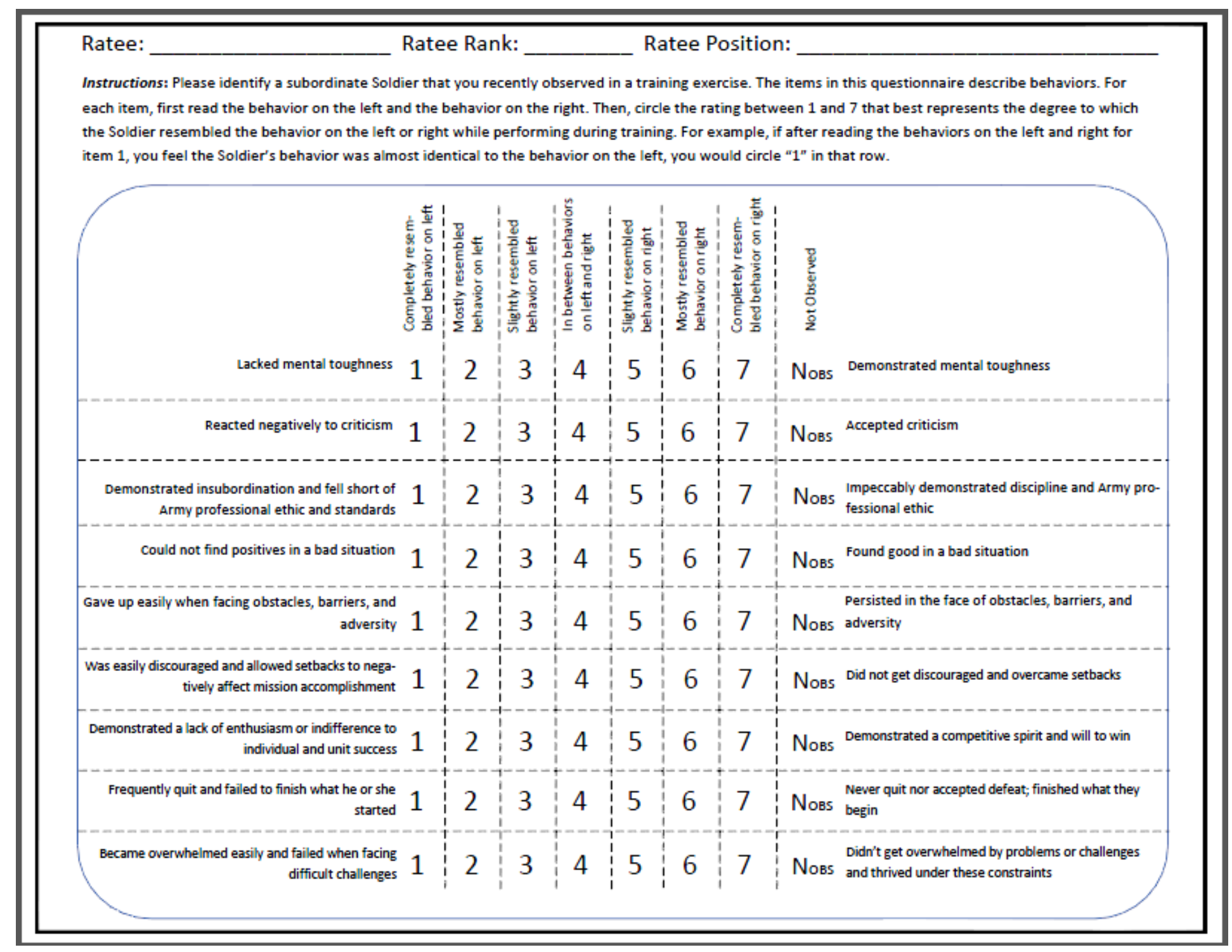




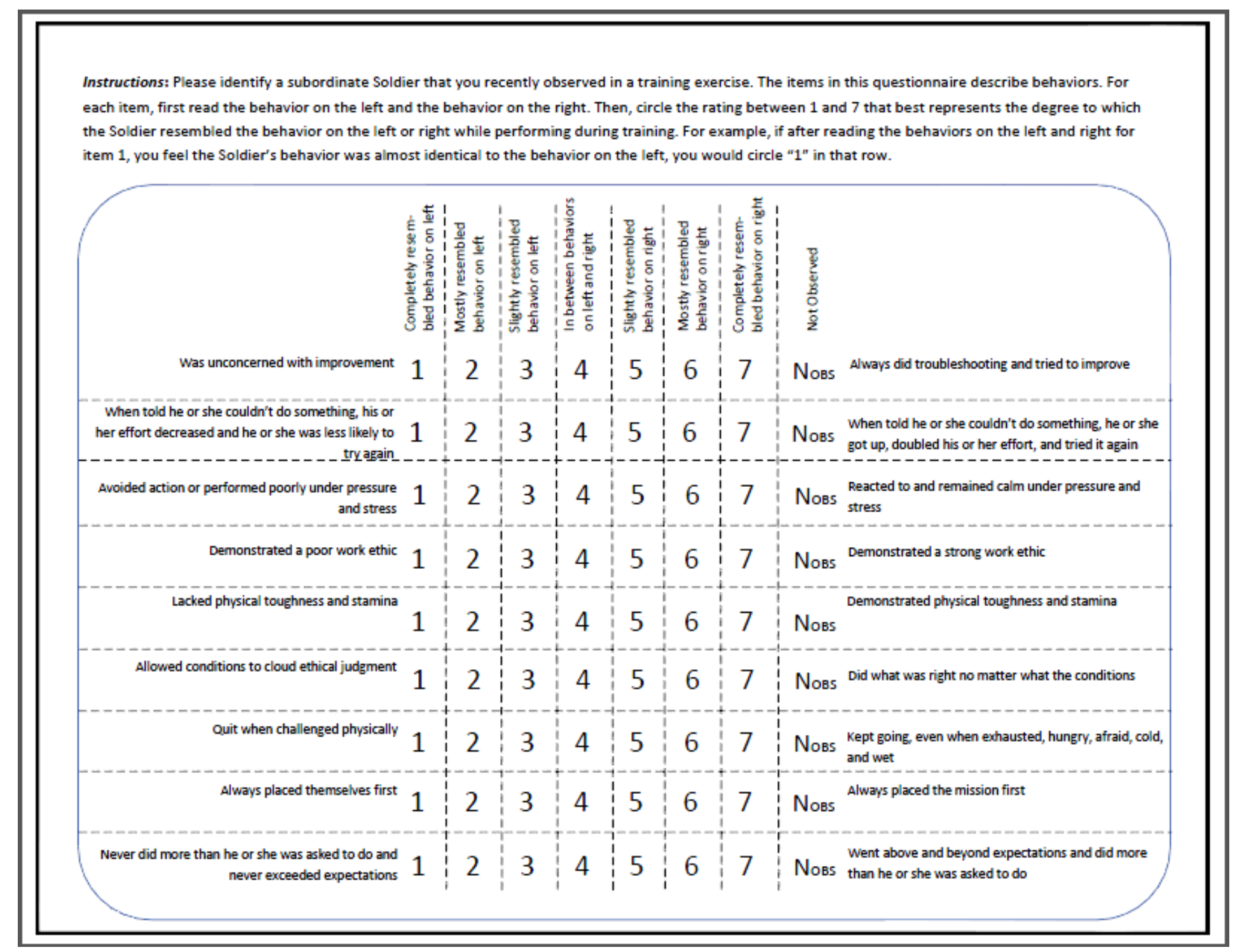




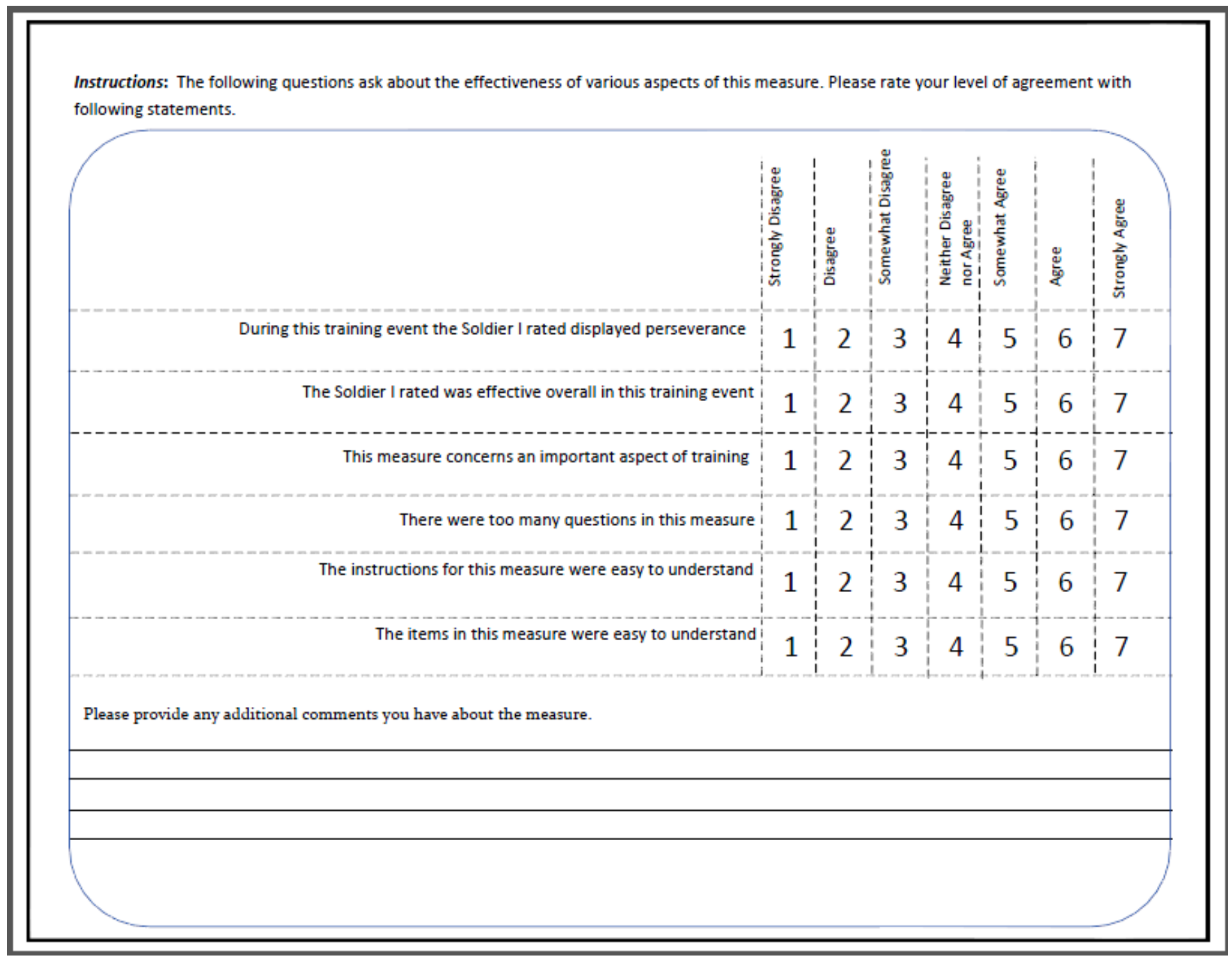




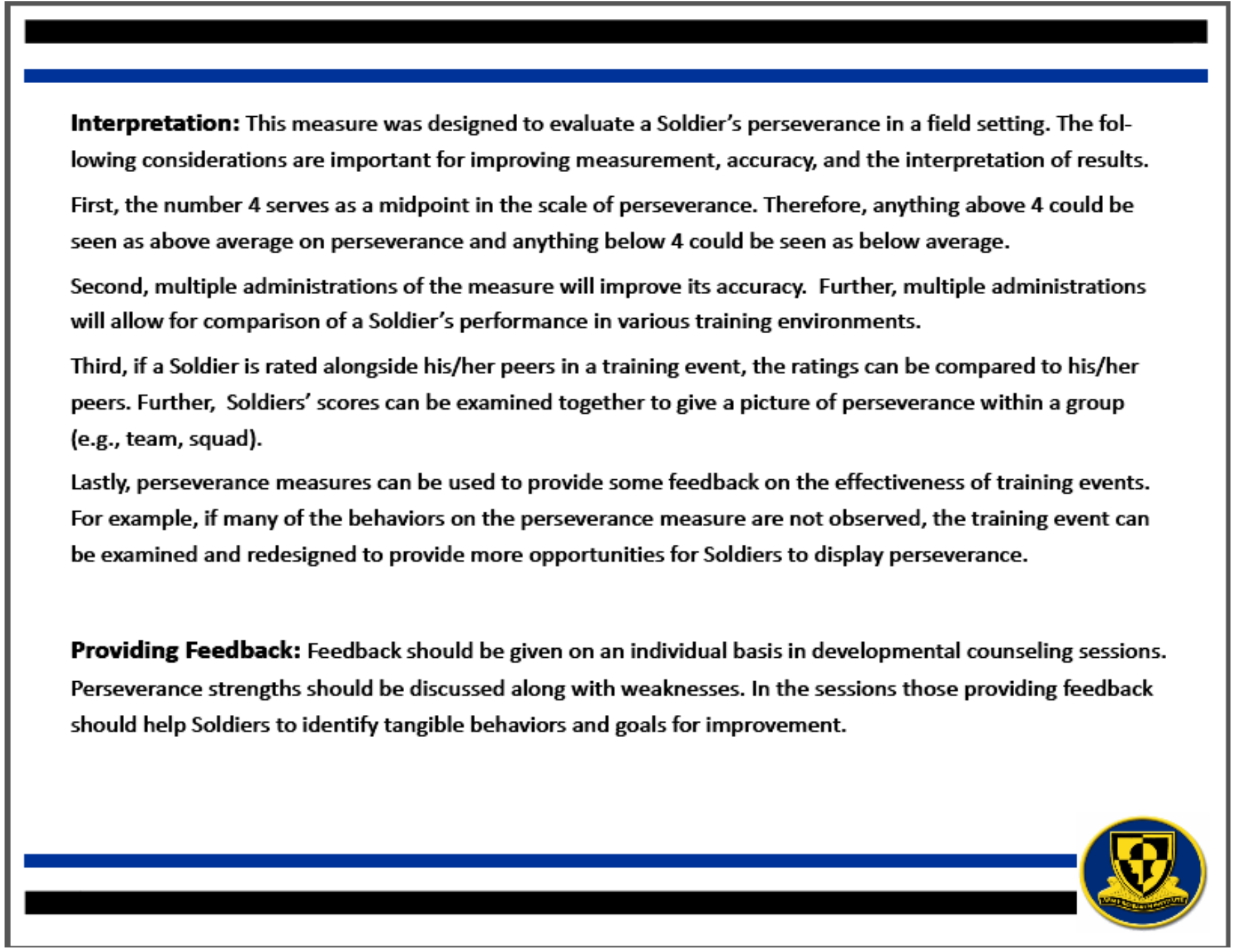

